\title{
Bony w wychowaniu domowym dzieci polskich w latach 1850-1914
}

W okresie zaborów, obok zrusyfikowanego i germanizowanego szkolnictwa państwowego alternatywną formą edukacji dzieci było nauczanie domowe. Praktykowane było ono na terenie wszystkich trzech zaborów, głównie wśród rodzin zamożnych, które stać było na zatrudnienie płatnych nauczycieli i wychowawców dzieci. W tychże rodzinach, zanim dziecko rozpoczęło systematyczną naukę pod kierunkiem prywatnego guwernera czy guwernantki, już kilka lat wcześniej angażowano do niego specjalną opiekunkę, wychowawczynię - zwaną boną.

Mimo prowadzonych $w$ ostatnich latach badań nad wychowaniem i nauczaniem domowym dzieci w XVIII, XIX i początkach XX w. ${ }^{1}$, temat bon nie został jeszcze do tej pory szerzej podjęty ${ }^{2}$. Istnieją wprawdzie pewne, mniej lub bardziej obszerne wzmianki na ten temat, przy okazji artykułów mówiących o nauczycielach domowych ${ }^{3}$, są one jednak jedynie sygnalizacją problemu. Dlatego też celem niniejszego opracowania jest analiza zbiorowości tych najemnych sił pedagogicznych, biorących udział w wychowaniu i nauczaniu dzieci polskich w okresie 1850-1914 ${ }^{4}$. Artykuł jest próbą udzielenia odpowiedzi

\footnotetext{
'Patrz np.: Wychowanie $w$ rodzinie od starozytnosici po wiek XX, red. J. Jundziłl, Bydgoszcz 1994; Rodzina jako środowisko wychowawcze w czasach nowożtnych, red. K. Jakubiak, Bydgoszcz 1995; T. Epsztein, Edukacja dzieci $i$ mlodzieży w polskich rodzinach ziemianskich na Wolyniu. Podolu $i$ Ukrainie w II polowie XIX wieku, Warszawa 1998; Wychowanie w rodzinie polskiej od schylku XVIII do polowy XX wieku, red. K. Jakubiak, A. Winiarz, Bydgoszcz 2000; Partnerka, matka, opiekunka. Status kobiety dziejach nowożytnych od XVI do XX wieku, red. K. Jakubiak, Bydgoszcz 2000; Dziecko w rodzinie i spoleczeństwie. Dzieje nowożytne, red. K. Jakubiak, W. Jamrożek, Bydgoszcz 2002; W. Korzeniowska, Edukacja $i$ wychowanie rózinych warstw spolecznych na ziemiach polskich od drugiej polowy wieku XIX do roku 1918, Kraków 2004; Nauczanie domowe dzieci w rodzinie polskiej, red. K. Jakubiak, A. Winiarz, Bydgoszcz 2004.

${ }^{2}$ Jedynym artykułem mówiącym o bonach jest praca W. Leżańskiej, Bony i freblanki w polskim systemie wychowania domowego, w: Nauczanie domowe dzieci..., op.cit., a także: B. Sandler, Wychowanie przedszkolne $i$ ksztalcenie wychowawczyń w Królestwie Polskim, Wrocław-Warszawa-Kraków 1968.

${ }^{3}$ Patrz np.: Z. Chyra, Nauczyciele prywatni (1765-1807), w: Spoleczenistwo polskie XVIII i XIX wieku, red. J. Leskiewiczowa, t. VI, Warszawa 1974; W. Leżańska, Nauczanie domowe w polskim systemie edukacyjnym, „Wychowanie Przedszkolne”, R. 9 nr 2; A. Winiarz, Czynniki determinujqce proces wychowania $w$ rodzinie polskiej doby niewoli narodowej (1795-1918), w: Wychowanie w rodzinie od starożytności...; J. Zacharska, Nauczycielka w literaturze przelomu XIX i XX wieku, w: Kobieta i Praca. Wiek XLX i XX. Zbiór studiów, red. A. Żarnowska i A. Szwarc, t. VI, Warszawa 2000; B. Hadaczek, Postać pedagoga w literaturze polskiej. Rozprawy i studia, t. XII, Warszawa-Poznań 1977; G. Karłowska, M. Nawrot, Charakterystyka zbiorowości nauczycieli domowych $w$ Królestwie Polskim $w$ świetle literatury wspomnieniowej i pamiętnikarskiej, „Acta Universitatis Nicolai Copernici”, Pedagogika XXIII, Torun 2004.

${ }^{4}$ Dokładną charakterystykę kultury i oświaty polskiej w dobie zaborów odnaleźć można m.in. w: R. Wroczyński, Dzieje oświaty polskiej 1795-1945. Warszawa 1980; P. Wandycz, Pod zaborami 1795-1918, War-
} 
na pytania, kim były bony, jakie było ich pochodzenie narodowe i społeczne, w jakim celu były zatrudniane, jakie były ich obowiązki i zadania? Istotne jest także ustalenie, jaka panowała w badanym okresie opinia wyrażana zarówno przez publicystów pedagogicznych, jak i społeczeństwo na temat bon cudzoziemek i Polek? Warto też przyjrzeć się, jakie były realia życia tychże osób, warunki pracy, a także ich stosunki z uczniami i pracodawcami? Temat ten jest jednak tak obszerny i złożony, iż niniejsza praca stanowi jedynie przyczynek do koniecznych dalszych, pogłębionych badań. Dokonane tu analizy oparte są w znacznej mierze na literaturze o charakterze pedagogicznym i poradnikowym dla rodziców i nauczycieli z XIX i początku XX w.5 , prasie pedagogicznej, kobiecej i rodzinnej z tegoż okresu ${ }^{6}$, które to źródła stanowią doskonałą bazę dla określenia stopnia i zakresu zainteresowania ówczesnych publicystów i pedagogów analizowanymi grupami trudniącymi się wychowaniem i nauczaniem dzieci w badanym czasie, a także ukazują stanowisko społeczeństwa $w$ tej sprawie. Należy podkreślić, że przeważają tu materiały pochodzące z zaboru rosyjskiego, co spowodowane jest faktem, iż to właśnie w tym zaborze (szczególnie w Warszawie) najbardziej rozwinięty był ruch wydawniczy na polu wychowania i nauczania dzieci. Ukazujące się tu czasopisma czy publikacje zwarte swoją problematyką nie ograniczały się jednak do stosunków panujących tylko w zaborze rosyjskim, ale odnosiły się również do sytuacji nauczania domowego na pozostałych terenach kraju. Prasa kobieca, rodzinna i pedagogiczna rozchodziła się także (choć w niezbyt licznych nakładach) na terenie wszystkich trzech zaborów, dlatego też publikowane na jej łamach porady, wskazówki czy zalecenia dotyczące wychowania i nauczania domowego dzieci, adresowane były zwykle do czytelników ze wszystkich części kraju. Podobnie było z literaturą pedagogiczna, która wydana w jednym zaborze, mogła być czytywana w pozostałych, jeśli oczywiście nie została wcześniej zabroniona przez cenzurę rządową. Równie ważną dla uzupełnienia analizowanego zagadnienia bazą źródłową będą materiały wspomnieniowe i pamiętnikarskie, na podstawie których postaram się odtworzyć realia i praktykę wychowania i nauczania dzieci w latach 1850-1914?

szawa 1994; J. Maternicki, Edukacja historyczna spoleczenistwa polskiego w XLX wieku, Warszawa 1981; M. Bogucka, Dzieje kultury polskiej do 1918 roku, Wrocław-Łódź 1987; B. Wasylewski, Życie polskie w XLX wieku, Kraków 1962; S. Kieniewicz, Historia Polski 1995-1912, Warszawa 1983; idem, Polska XIX wieku. Państwo. Spoleczeństwo. Kultura, Warszawa 1987.

${ }^{5} \mathrm{O}$ wartości i sposobach wykorzystania tego typu źródeł piszą m.in.: K. Jakubiak, Źródlia do dziejów wychowania $w$ rodzinie polskiej $z$ XIX $i$ początków XX wieku, w: Źródla $w$ badaniach naukowych historii edukacji, red. W. Szulakiewicz, Toruń 2003; idem: Popularyzacja wychowania rodzinnego dziecka w polskiej literaturze pedagogicznej i czasopiśmiennictwie XIX wieku, w: Rodzina $w$ starożytnym Rzymie, red. J. Jundzilł, Bydgoszcz 1993; J. Sobczak, Warunki i przejawy rozwoju teorii wychowania rodzinnego $i$ edukacji rodziców od czasów Odrodzenia. w: Rodzina. Przeszlość-Teraźniejszość-Przyszlość, red. A. Tchorzewski, Bydgoszcz 1988; E. Chałasińska, Problemy rodziny $i$ sprawa kobieca w publicystyce dziewiętnastowiecznej, „Problemy Rodziny” 1969, nr 4/48.

${ }^{6}$ Ze względu na rozległość czasową i terytorialną prowadzonych analiz będą to jedynie wybrane tytuły; o cenności prasy w badaniach historyczno-oświatowych pisali m.in.: A. Kicowska, Prasa jako źródlo w badaniach historii wychowania, w: Metodologia w badaniach naukowych historii wychowania, red. T. Jałmużna, I. G. Michalscy, Łódź 1993; B. Krzywobłocka, Prasa jako źródlo historyczne, w: Metody i techniki badawcze w prasoznawstwie, t. III, Warszawa 1971; W. Pisarek, Analiza zawartości prasy, Kraków 1983.

${ }^{7}$ Patrz np.: J. Deresiewicz, Uwagi o pamiętnikach jako źródle historycznym, „Pamiętnikarstwo Polskie” 1976, nr 1-4; F. Jakubczak, Metodologiczne problemy użytkowania pamiętników, w: Ruch pamiętnikarski i przemiany kultury polskiej, red. Z. Krzemień, Warszawa 1972; B. Matus, Bez pamiętników nie ma historii, 
Bona, jak podaje Encyklopedia powszechna z roku 1860, to wyraz pochodzenia francuskiego (bonne), oznaczający piastunkę, pokojówkę. Wyraz od niejakiego czasu rozpowszechniony u nas, na oznaczenie osób plci żeńskiej, zwykle z zagranicy sprowadzanych, $w$ celu dozorowana drobnych dzieci i przyuczania ich obcego języka ${ }^{8}$. Dykcjonarz z roku 1859 określa bonę jako wyraz pochodzenia francuskiego, oznaczający dozorczynię dzieci, niańke dość uksztalcona 9 . Podobnie Slownik języka polskiego z roku 1861 definiuje ja jako dozorczynię dzieci, niańkę dość uksztalconq, niekiedy oznacza wyslużonq niańkę, lub dozorczynię dzieci, jakby pannę respektowq ${ }^{10}$. Z kolei Stownik ilustrowany języka polskiego M. Arcta z roku 1916 podaje, iż bona to dozorczyni dzieci z konwersacja francuskq ${ }^{11}$.

Bony zwykle zatrudniano w rodzinach możnych, szlachecko-ziemiańskich, mieszczańskich czy arystokratycznych. W tych właśnie rodzinach dziecku od chwili narodzin towarzyszyły najemne opiekunki, nianie, piastunki, wychowawczynie, nauczycielki czy nauczyciele domowi. Bony były więc jednymi z wielu osób trudniących się wychowaniem i nauczaniem młodego pokolenia. Do najmłodszych dzieci - niemowląt - zatrudniano mamki, które obok karmienia dziecka piersią, zajmowały się nimi przez całą dobę. Po zakończeniu okresu karmienia, dla dziecka najmowano nianię-piastunkę, której zadaniem również była całodobowa opieka nad powierzonym maluchem. Do obowiązków mamki i niani należała głównie troska o prawidłowy rozwój fizyczny dziecka, dbałość o higienę, prawidłowe odżywianie, ubranie. Gdy dziecko zaczynało płynnie mówić, czyli około 3 roku życia, rodzice poszukiwali zwykle specjalnej opiekunki - bony, której powierzano pieczę już nie tylko nad rozwojem fizycznym, ale przede wszystkim intelektualnym dziecka. Powierzony bonie wychowanek pozostawał pod jej opieką przez kilka lat, aż do rozpoczęcia systematycznej nauki domowej, prowadzonej zwykle pod kierunkiem guwernantki czy guwernera.

Mimo że zatrudnianie bon najpopularniejsze było w możnych rodzinach, to, jak wskazują źródła, zdarzało się, że i u średniozamożnego ziemiaństwa i mieszczaństwa, przemysłowców, urzędników, spotkać można było tę najemną pomoc w wychowaniu młodszych dzieci ${ }^{12}$. Już samo bowiem posiadanie bony do dziecka podnosiło niejako pre-

w: Pól wieku pamiętnikarstwa, wybór i oprac. S. Adamczyk, S. Dyksiński, F. Jakubczak, Warszawa 1971; R. Lubas-Bartoszyńska, Style wypowiedzi pamiętnikarskiej, Kraków 1983; A. Kicowska, Pamiętniki jako iródlo badań nad dzieckiem $i$ dzieciństwem, w: Dziecko $w$ rodzinie $i$ spoleczeństwie....

${ }^{8}$ Encyklopedia powszechna, Warszawa 1960, tom IV, s. 29.

${ }^{9}$ Dykcjonarz zawierajacy wyrazy $i$ wyrażenia z obcych jezyków polskiemu przyswojone (...) Michala Amszejewicza, Warszawa 1859 , s. 63.

${ }^{10}$ Slownik języka polskiego do podręcznego użytku, wypracowany przez A. Zdanowicza i innych, Wilno 1861, część I, s. 98.

${ }^{11}$ Slownik ilustrowany języka polskiego M. Arcta, Warszawa 1916, s. 17; Trudno jest określić, kiedy w Polsce zaprowadzono zwyczaj zatrudniania bon. Już kilka stuleci wcześniej znakomite rody oddawały kierownictwo dzieci rodowitym Francuzkom i jak można przypuszczać, już wtedy wyraz bonne, oznaczający po francusku służąca, został przyswojony i przekształcony na bona, za: Rodzina. Bona, „Biesiada Literacka" 1892, nr 41, s. 230.

${ }^{12}$ Arystokracja nasza przyszla już dzisiaj do rozumu, że trzeba uczyć swe dzieci w ojczystym języku. nie zaniedbujac $i$ obcych $w$ miarę umyslowego rozwijania się. Blad i grzech wzięla teraz na siebie klasa średnia, zamożna, która za pierwszy szczebel przyszlej kariery uważa francuszczyzne $i$ angielszczyzne, wpajanq w dzieci swe od pierwszych lat, gdy zaledwie mówić zaczynaja, Poklosie, „Kłosy” 1877, nr 621, s.338; Nie 
stiż rodziny - bonę po prostu wypadało mieć, wszakże dzieci "pod okiem bon" wychowywane, to już musza być dzieci do wyższej klasy należace; to slowem coś "lepszego", coś co do dobrego tonu $i$ arystokratycznych manier należy ${ }^{13}$ - uważano powszechnie wśród społeczeństwa, zaś publicyści pedagogiczni nazwali to zjawisko ,zagranicomanią" Dlatego też większość bon sprowadzanych do kraju, była pochodzenia francuskiego, niemieckiego, szwajcarskiego, angielskiego ${ }^{15}$. Zadaniem oczywiście takiej zagranicznej bony było nauczenie dziecka języka kraju, z którego pochodziła. W wielu bogatych rodzinach praktykowano zatrudnianie kilku bon jednocześnie, by uczyć dziecko konwersacji w kilku językach naraz ${ }^{16}$.

Tabela: Pochodzenie narodowe i liczba bon zatrudnianych w rodzinach polskich od drugiej polowy XIX w. do roku 1914 w świetle badanych pamiętników

\begin{tabular}{|l|c|c|c|c|c|c|}
\hline \multirow{2}{*}{ Narodowość } & \multicolumn{5}{c|}{ Typ rodziny } & \multirow{2}{*}{ Razem } \\
\cline { 2 - 7 } & chlopska & robotnicza & $\begin{array}{c}\text { miesz- } \\
\text { czańska }\end{array}$ & $\begin{array}{c}\text { szlachecko- } \\
\text {-ziemiańska }\end{array}$ & $\begin{array}{c}\text { arystokra- } \\
\text { tyczna }\end{array}$ & \\
\hline Zabór rosyjski & & & 2 & 10 & & 12 \\
\hline Polka & & & 8 & 13 & & 21 \\
\hline Francuzka & & & 5 & 8 & & 13 \\
\hline Niemka & & & 1 & & & 1 \\
\hline Angielka & & & & 1 & & 1 \\
\hline Lotewka & & & 8 & 9 & & 17 \\
\hline Brak określenia & & & & & & \\
\hline
\end{tabular}

ma chyba drugiego kraju, w którym bony bylyby tak poszukiwane jak u nas. Bogatsi rodzice od pierwszych lat życia sprowadzaja Francuzki, Angielki, Niemki, średniozamożni gotowi sq od urodzenia niemowlęcia skladać pieniqudze, by mieć choćby przez lat kilka jakq mniej wymagajqca cudzoziemkę, I. Z., Jakie bony otrzymujemy z Paryża, „Przegląd Pedagogiczny” 1890, nr 5, s. 52.

${ }^{13}$ J. Jeleński, Bony, „Opiekun Domowy” 1875, nr 41, s. 1; Sredniozamożni gotowi sq od urodzenia niemowlęcia skladać pieniqdze, by mieć choćby przez kilka lat jakq mniej wymagajqcq cudzoziemkę; biedni z zazdrosicia patrzq, jak dzieci bogatszych spaceruja i paplq z kapeluszowq strojna pannq, gdy ich dzieciaki bawiq się same i gwarzq w powszechnie zrozumialym rodzinnym języku, I.Z., op.cit., s. 52.

${ }^{14}$ Czy nie należaloby pamiętac, że sprowadzając setki bon cudzoziemek $i$ szerzac tym samym zagranicomanię wyrzadzamy sami sobie krzywdę, jakiej korzyść z lichej znajomości francuszczyzny nigdy $i$ w żadnym razie zrównoważyć nie zdola?, J. J., Praca kobiet u nas. Bony Polki, „Biesiada Literacka” 1876, nr 32, s. 504.

${ }^{15}$ Dotqd $u$ wielu jeszcze trwajqcy przesqd, który stawial na pierwszym planie wychowania akcent $i$ wymowe francuska, tak wplynal na obyczaj ogólny, iz wylqcznie do dzieci poszukiwane byly Francuzki, Szwajcar$k i$, a wreszcie Niemki. $Z$ tego powodu ten rodzaj zarobku byl niedostepny dla kobiet naszych, a w nastepstwie bona Polka stala się prawdziwq rzadkościq, J. Olszyc, Proletariat kobiecy V, Bony czyli dozorczynie malych dzieci, „Kronika Rodzinna” 1877, nr 18, s.275; Jak donosiła w odpowiedzi na zamieszczony na łamach „Bluszczu" Kwestionariusz Rodzinny nauczycielka domowa z 27 -letnim stażem, matki dzisiejsze osobiście mniej się wychowaniem zajmuja więcej je zdaja na ręce cudze, z rak piastunki oddaja je bezpośrednio w ręce bony i to najczęściej cudzoziemki, Kwestionariusz Rodzinny, „Bluszcz” 1886, nr 8, s. 58.

${ }^{16}$ Jak wspominała Maria Kuncewiczowa, zamieszkała w Królestwie Polskim, od najmłodszych lat przydzielono jej dwie bony cudzoziemki: Zostalam powierzona dwu konwersacjonistkom - Frauleiny Helene Goertz, z która chodzilam na spacery nienieckie i Mlle Suzanne Belletout, z którq chodzilam na spacery francuskie, w: M. Kuncewiczowa, Fantomy, Warszawa 1972, s. 51. 


\begin{tabular}{|c|c|c|c|c|c|c|}
\hline \multirow[b]{2}{*}{ Narodowość } & \multicolumn{5}{|c|}{ Typ rodziny } & \multirow[b]{2}{*}{ Razem } \\
\hline & chlopska & robotnicza & $\begin{array}{l}\text { miesz- } \\
\text { czańska }\end{array}$ & $\begin{array}{l}\text { szlachecko- } \\
\text {-ziemiańska }\end{array}$ & $\begin{array}{l}\text { arystokra- } \\
\text { tyczna }\end{array}$ & \\
\hline \multicolumn{7}{|l|}{ Zabór pruski } \\
\hline Polka & & & 1 & 6 & & 7 \\
\hline Francuzka & & & & & 1 & 1 \\
\hline Niemka & & & 1 & & & 1 \\
\hline Szwajcarka & & & & 1 & & 1 \\
\hline Brak określenia & & 1 & & & & 1 \\
\hline \multicolumn{7}{|c|}{ Zabór austriacki } \\
\hline Polka & 1 & & 1 & 3 & & 5 \\
\hline Francuzka & & & & 1 & & 1 \\
\hline Niemka & & & & 5 & & 5 \\
\hline Angielka & & & & 1 & & 1 \\
\hline Razem & 1 & 1 & 27 & 58 & 1 & 88 \\
\hline
\end{tabular}

Na podstawie analizy ok. 400 pamiętników z okresu 1850-1914, ze wszystkich trzech zaborów $^{17}$, udało się ustalić, iż w analizowanym okresie zajęciem bony trudniło się 88 kobiet. Najwięcej z nich, bo 58 pracowało w rodzinach szlachecko-ziemiańskich (najwięcej w zaborze rosyjskim - 41, potem z zaborze austriackim - 10, a najmniej z zaborze pruskim - 7), na drugim miejscu pod względem zatrudniania bon były rodziny mieszczańskie - 27 bon (najwięcej z zaborze rosyjskim - 24, 2 w zaborze pruskim i 1 w zaborze austriackim), na ostatnim zaś miejsce, jak podają pamiętnikarze, bo po 1 bonie, pracowało w rodzinach chłopskich i robotniczych.

Analizując pochodzenie narodowe zatrudnianych w rodzinach polskich bon, udało się ustalić, iż najczęściej zatrudniano Francuzki (21 w zaborze rosyjskim, 1 w zaborze pruskim i $1 \mathrm{w}$ zaborze austriackim), następnie Polki (12 w zaborze rosyjskim, $7 \mathrm{w}$ zaborze pruskim i $5 \mathrm{w}$ zaborze austriackim), Niemki (13 w zaborze rosyjskim, $1 \mathrm{w}$ zaborze pruskim i $5 \mathrm{w}$ zaborze austriackim). Zdecydowanie rzadziej w rodzinach pamiętnikarzy zatrudniano Angielki, wspominają oni o zaledwie 2 bonach tej narodowości (1 w zaborze rosyjskim i $1 \mathrm{w}$ austriackim). Dwie bony, jak podają analizowane źródła były pochodzenia łotewskiego i szwajcarskiego. W przypadku 18 bon trudniących się wychowaniem dzieci w rodzinach polskich w analizowanym okresie, autorzy wspomnień nie podają ich narodowości (17 takich przypadków pochodziło z zaboru rosyjskiego i 1 z zaboru austriackiego).

Dane wynikające $\mathrm{z}$ analizy pamiętników nie są niestety reprezentatywne dla populacji bon pracujących $w$ analizowanym okresie na terenie ziem polskich. Jak wynika $z$ badań, największa liczba bon pracowała w zaborze rosyjskim, spowodowane jest to jednak faktem, iż przeanalizowano największą liczbę pamiętników właśnie z tego zaboru, ponieważ tychże pamiętników opublikowano do tej pory najwięcej. Podobnie tak popularne

\footnotetext{
${ }^{17}$ Patrz aneks nr 1.
} 
zatrudnianie bon $w$ rodzinach arystokratycznych jest zupełnie niewidoczne na podstawie analizy pamiętników, ponieważ dokonano analizy zaledwie 7 takich publikacji. Również zatrudnianie bon - Niemek w zaborze pruskim, tak krytykowane przez publicystów pedagogicznych w końcu XIX i początku XX w., nie znalazło tutaj zupełnie swego odzwierciedlenia. Owa rozbieżność ustaleń dokonanych na podstawie źródeł prasowych i literatury pedagogicznej, a tych zgromadzonych na podstawie literatury wspomnieniowej i pamiętnikarskiej, spowodowana jest nierówną liczbą pamiętników pochodzących z poszczególnych zaborów i z poszczególnych typów rodzin, ponieważ takie bądź nie powstały, bądź nie zostały do tej pory opublikowane, więc nie mogły zostać zgromadzone na potrzeby niniejszych analiz. Ale przede wszystkim przyczyną rozbieżności jest specyfika źródeł pamiętnikarskich, które ze względu na swój subiektywizm i możliwe zafałszowania rzeczywistości zwykle stanowią jedynie dodatek do badań, a w tym przypadku stały się podstawą badania pochodzenia narodowego zbiorowości bon zatrudnianych na ziemiach polskich $w$ analizowanym okresie. Jednak mimo tych rozbieżności, dokonane analizy stanowią pewien, choć z pełną świadomością należy stwierdzić, że niepełny, obraz pochodzenia narodowego bon zatrudnianych w poszczególnych typach rodzin polskich w latach 1850-1914 w świetle właśnie źródeł wspomnieniowych i pamiętnikarstwa.

Przyczyną zatrudniania bon cudzoziemek na terenie ziem polskich pozostających pod panowaniem zaborców była panująca moda na cudzoziemszczyznę, szczególnie francuszczyznę. Była ona szczególnie popularna w pierwszej połowie XIX w., lecz i w kolejnych dziesięcioleciach, mimo szeroko zakrojonej krytyki, nasilonej szczególnie w końcu wieku XIX i początku wieku XX, nadal panowała wśród wielu polskich rodzin ${ }^{18}$. Uczono więc języka francuskiego głównie dla względów salonowej elegancji ${ }^{19}$. Jak uważali ówcześni publicyści pedagogiczni, zwykle zaczynano naukę od języków obcych raczej dla popisu i milości wlasnej rodziców, pozorujących sprawę tym, że dziecko ma , większa latwość do jezzyków" ${ }^{20}$. W zaborze pruskim zaś, obok mody na bony cudzoziemki, zatrudnianie bon - głównie Niemek, służyło nauce języka, którym dziecko posługiwać się miało w przyszłości w szkołach.

Dziecko przekazywane bonie miało zazwyczaj ukończone 3-4 rok życia i pozostawało pod jej opieką do ukończenia 6-7 roku życia, czyli do rozpoczęcia systematycznej nauki ${ }^{21}$. Do obowiązków bony, obok nauki języka obcego, należało także (o ile dziecko nie miało jednocześnie niani, która by te zadania wykonywała): całodobowa

\footnotetext{
${ }^{18}$ Tak pisał w 1901 r. o panującej ciągle modzie na cudzoziemszczyznę Znicz: poczciwe polskie nianie $i$ piastunki zostaly oddalone od kolebek dzieci, gdyz sprowadza się bony wprost z Paryza, z akcentem paryskim, bo to dziś modne! A moda to potęga wszechwladna, któżby śmial jej uchybic??!, w: Znicz, Rodzina. Nianiusia $i$ bona, „Biesiada Literacka” 1901, nr 40, s. 277.

${ }^{19}$ M. Ilnicka, Do rodziców, „Bluszcz” 1888, nr 24, s. 187.

${ }^{20}$ Dr., $O$ zdrowie naszych dzieci, „Ziarno" 1907, nr 52, s. 9.

${ }^{21}$ Jak wspominała mieszkanka Prus, Maria Malgorzata z Radziwiłlów Franciszkowa Potocka, pierwszą bonę, Francuzkę, zatrudniono do niej, gdy ukończyła 4 lata, w: M M. z Radziwiłłów Franciszkowa Potocka, Z moich wspomnień. Pamiętnik, Warszawa 1978, s. 97; Z kolei Krzysztof Mikolaj książę Radziwilł wspomina, iż mnie, jako siedmioletniego chlopca, bony myty $i$ znosily ze schodów, K. M. Radziwiłł, Pamiętniki. Od feudalizmu do socjalizmu bezpośrednio, Warszawa 2000, s. 23.
} 
opieka nad dzieckiem $^{22}$, mycie, ubieranie, czesanie, karmienie ${ }^{23}$, dbanie o pokój dziecka i utrzymanie go w czystości i porządku, organizowanie, a często i uczestniczenie w zabawach dziecka ${ }^{24}$, dbałość o wychowanie fizyczne, spacery ${ }^{25}$, gimnastykę itd. ${ }^{26}$ Zadaniem bon było też ksztaltowanie moralności u swych podopiecznych, a więc tłumienie wszelkich złych uczuć, popędów lub kaprysów dziecka, wykorzenianie egoistycznych skłonności malców, a także dbanie o rozwój etycznych pojęć dzieci przez pobudzanie uczuć moralnych i religijnych ${ }^{27}$. Tak wspominał Władysław Jan Grabski, zamieszkały w Królestwie Polskim, bony towarzyszące dzieciom całą dobę: bony nas pilnujq i uczq ladnie postepować, mówić i jeść. Zewszqd styszę: Wladziu, chodź, Wladź, popatrz tu albo tam, wytrzyj nos, przeżegnaj się, podziękuj, powiedz do widzenia. Ciagle nas czegoś uczq. zawsze sq przy nas wazne 28 .

Bywało także, że bony obok opiekowania się dziećmi, zajmowały się pomocą w gospodarstwie domowym. Jak pisała do matek publicystka z Prus, Karolina Nakwaska: Niech ona (bona) ci pomaga $w$ domowych pracach, $w$ smazeniu konfitur, $w$ rozdawaniu lekarstw. Dobrze, że się do tego wprawi i będzie cię zastapić mogla w słabości ${ }^{29}$.

${ }^{22}$ Eliza z Branickach Krasińska, zamieszkała w zaborze rosyjskim pisala, iż synek jej potrzebuje ciagłej opieki a nikt lepiej jak doskonala bona nie może mu jej zapewnić. On sypia jeszcze przy niej, gdyż trzeba do niego wstawać, przykrywać go, zmieniać mu koszulę itd., w: Swiadek epoki. Listy Elizy z Branickich Krasińskiej z lat 1835-1876, t. 3, Warszawa 1996, s. 98.

${ }^{23}$ Izabela Stachowicz, mieszkająca w zaborze rosyjskim wspominała: Pierwsza moja bona, fraulein Marta pilnowala, żebym podczas śniadania nie oblala się mlekiem i ladnie jadla bulkę, w: Czajka (Izabela Stachowicz), Córka czarownicy na huśtawce, Warszawa 1958, s. 23.

${ }^{24}$ Wspólne $\mathrm{z}$ bona zabawy zimowe, a także urzadzanie pod jej kierunkiem teatrzyku amatorskiego wspomina mieszkanka Prus, Jadwiga Żylińska, w: J. Żylińska, Dom, którego nie ma, Warszawa 1967, ss. 22, 30-32.

${ }^{25} \mathrm{O}$ wspólnych, codziennych rannych spacerach $\mathrm{z}$ boną Niemką wspominał Władysław Lednicki, zamieszkały w zaborze rosyjskim, w: Pamiętniki, Londyn 1963, s. 34.

${ }^{26}$ Jak pisal A. Potocki, dzieci bywaja oddawane pod nadzór bon, od nich otrzymuja napomnienia, nauki, $z$ nimi spędzajq znacznq cześć czasu wolnego, wreszcie nierzadko z bonq rozpoczynaja nauke czytania $i$ pisania w obcym jezyku, w: A. Potocki, Slugi - wychowawczynie, „Przeglad Pedagogiczny” 1893, nr 8, s. 101.

${ }^{27} \mathrm{M}$. Ch., O gderaniu na dzieci, „Wędrowiec” nr 49, Warszawa 1894; Bona wiele może zrobić w kierunku religijno-moralnym, bo do niej, jako zastepczyni matki, należy zaszczepianie uczucia religijnego. Przyklad wywiera na dzieci wptyw ogromny, gdyż nauka tylko uczy, a on pociaga. Opiekunka więc winna dla dziecka być wzorem bogobojności, ściśle wypelniać przepisy Kościola, rozwijać pojecia o Bogu, jego wszechmocy. Uczucie religijne obudzi w sercu dziecka milośc bliźniego, chęć niesienia pomocy biednym, w: Rodzina. Bona, op.cit., s.230; Jednocześnie zwracano uwage, że bony cudzoziemki, często protestantki, bądż ateistki, nie są w stanie wpoić dzieciom religii w taki sposób, jak polskie matki, które właśnie bonom oddają dozór nad modlitwami i wychowaniem religijnym dziecka. Często powoduje to smutne następstwa, gdyż pod wpływem takiej bony wychowujqcej dziecko w braku bojażni Boga $i$ wszelkiej pobożności, rozwija się w dziecku sklonność do niesubordynacji, próżności, lenistwa i milości rozkoszy, w: Ks. F. Dupanloup, Listy o wychowaniu dziewcząt, przel. J. Kusztelanówna, Warszawa 1914, s. 217.

${ }^{28}$ W. J. Grabski, Blizny dziecinistwa, Warszawa 1971, s.14 (Królestwo Polskie).

${ }^{29} \mathrm{~K}$. Nakwaska, Dwór wiejski. Dzielo poświęcone gospodyniom polskim, przydatne $i$ osobom $w$ mieście mieszkajacym, przerobione $z$ francuskiego Pani Aglaë Adanson, z wielu dodatkami i zupelnym zastosowaniem do naszych obyczajów $i$ potrzeb, Poznań 1843, s. 168; dalej dokładnie opisywała całodzienny rozkład prac bony: Bona u ciebie próżnować też nie powinna. Po wstaniu dzieci, zaraz z rana ma je pomyć, poczesać, poubierać porzqdnie, choć w ranne sukienki. Ma się zajać ich śniadaniem. Przyprowadzi je do ciebie, potem wyjdzie z nimi do ogrodu, jeżeli czas po temu. Będzie o nich miala ciagle staranie, nie odstapi ich przy kapieli, albo broń Boże w slabości. Znowu je przed obiadem drugi raz ubierze, $a$ w chwilach wolnych, albo dla nich sukienki szyć, albo naprawiać bieliznę, albo pończochy robić ma, w: ibidem, s. 169. 
Jako że bony niejednokrotnie zupełnie zastępowały matkę $w$ wychowaniu i kształceniu dzieci ${ }^{30}$, ich rola była ogromna. Powierzone im dzieci były bowiem w wieku najsilniejszego fizycznego i moralnego rozwoju, a wpływ jaki wywierały opiekunki oddziaływał na całą ich przyszłość i charakter ${ }^{31}$. Dlatego też publicyści pedagogiczni ze wszystkich trzech zaborów zgodnie apelowali do rodziców o staranny wybór bon, sądząc, jak pisał Jan Olszyc, iż przy rozpowszechnieniu wiedzy nie watpię, że rodzice coraz baczniejszq zwracać będq uwagę na osoby, którym powierzaja ten pierwszy okres wychowania, czyli na bony ${ }^{32}$, a także wskazywali na cechy, którymi taka najlepsza bona powinna się charakteryzować ${ }^{33}$. Wprawdzie nie wymagano od niej gruntownego i wszechstronnego wykształcenia, lecz konieczne było posiadanie inteligencji, która posiadać trzeba, by taktownie z dziećmi postepować, by mieć właściwy sqd o dzieciach $i$ utrzymać miarę $w$ udzielaniu przestróg, kar $i$ nagród ${ }^{34}$. Inteligencja konieczna też była dla umiejętnego i zgodnego z rzeczywistością udzielania odpowiedzi na liczne pytania, którymi zasypuje wychowawczynię dziecko poznające świat ${ }^{35}$. Brak inteligencji u bon uniemożliwiał matkom współpracę i współdziałanie z opiekunką na polu wychowania, gdyż proste opiekunki często nie były w stanie zrozumieć, czego matka od nich wymagała i według jakich zasad pragnęła kierować dzieckiem.

Od dobrej bony wymagano także przymiotów charakteru i serca, jakich zadanie jej $z$ samej natury rzeczy $i$ bezsprzecznie wymaga ${ }^{36}$. Zaliczano do nich pogode ducha, rozsądek, cierpliwość, łagodność, miłość do dzieci i do otoczenia, wyrozumiałośćc ${ }^{37}$. Bona-wychowawczyni powinna być: sumienną i gorliwą w wypełnianiu swych obowiązków, uczciwą łagodną i wyrozumiałą, moralną, skromną i przyzwoitą, uprzejma, grzeczną i dobrze wychowana, sprawiedliwą i rozsądną, wesołą, porządną ${ }^{38}$. Powinna znać także zasady wychowania fizycznego i higieny ${ }^{39}$.

\footnotetext{
${ }^{30}$ Jak pisał jeden z pamiętnikarzy: Przesadq byloby twierdzić, że najważniejsza osoba mojego dziecinstwa byla panna Czesia, bona. Ale byla bardzo ważna osobq. I o wiele lepiej niz garderobę mamy znatem suknie panny Czesi, na których uczylam się kolorów [...] Mama nie lubila bawić się z dziećmi, dopóki byly male, w: J. Żylińska, op.cit., s. 21.

${ }^{31}$ Bona nie wiedzqc nawet niestety o tym, zaszczepia $w$ mlodocianej duszy pojęcia, których póżniej zadna sila może nie wyprze, bo zaszczepia je wtedy, kiedy wyobraźnia w calej duchowej atmosferze wychowanka jest wszechwladnq paniq $i$ kiedy wszelkie wptywy $i$ wrażenia pierwotnie najtrwalszymi się staja, w: J. Jeleński, op.cit., s. 1.

32 J. Olszyc, op.cit., s. 276.

${ }^{33}$ Określano nawet wiek, w którym powinna być bona, np. Karolina Nakwaska pisala: Staraj się o kobiete porzqdnq, nie zbyt mlodq - dobrze kiedy jest wdowq, matkq dzieciom, - bo się bardziej do twoich przywiqże, w: K. Nakwaska, op.cit., s. 167.

${ }^{34}$ A. Sobolewska, W sprawie wychowawczyń domowych, „Dziecko” 1914, nr 1, s. 5.

${ }^{35} \mathrm{~J}$. Olszyc, op.cit., s. 276.

${ }^{36} \mathrm{~J}$. Jeleński, op.cit., s. 1; Jeżeli więc osoba trudniqca się tym pierwszym wychowaniem, nie potrzebuje systematycznej nauki, potrzebuje za to moralnych przymiotów, cierpliwości, pracowilości i porzqdku. Cnoty te bowiem najlatwiej podpadaja pod uwage dziecka, a tym samym pobudzajac jego umysl naśladowczy, ksztalca w nim cnoty odpowiednie, w: J. Olszyc, op.cit., s. 276.
}

${ }^{37}$ A. Sobolewska, W sprawie wychowawczyń..., s. 6; Rodzina. Bona, s. 230.

${ }^{38}$ W książce W. Puffke, Zabawy, gimnastyka i pogadanki w szkólce freblowskiej zawarty jest osobny rozdział zawierający obowiązki bony-wychowawczyni do dzieci od 2 i pół do 5 roku życia, gdzie wszystkie ze wskazanych cech są dokładnie opisanie i wyjaśnione, jak bona ma się zachowywać, by taką wlaśnie być, np. Czy to $w$ obecności czy $w$ nieobecności matki wypelniać polecenia jej jak najdokladniej. Nie uczyć dzieci 
Poszukiwanie bony cudzoziemki odbywało się podobnie we wszystkich trzech zaborach - zwykle za pośrednictwem kantorów stręczen ${ }^{40}$, rzadziej za pośrednictwem rodziny

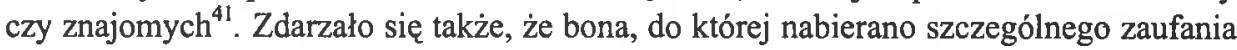
i która wyróżniała się efektywnością w wychowaniu dzieci, przekazywana była sobie $\mathrm{z}$ rodziny do rodziny ${ }^{42}$. Innym, popularnym sposobem poszukiwania bon była prasa, na łamach której rodzice umieszczali swoje ogłoszenia, zawierające jednocześnie ich wymagania i oczekiwania wobec kandydatki, i to nie tylko co do jej wykształcenia, ale i moralności, a nawet wyglądu zewnętrznego ${ }^{43}$. Zdarzało się także, że na łamach prasy pojawiały

klamstwa, nie obiecywać lakoci za różne nierzetelności przed starszymi. Niech się bona nie żali na rodziców przy dzieciach, niech ich nie obmawia, nie krytykuje. Źle się z dzieckiem nie obchodzić, nie karcić, grubiańskich wyrazów nie używać. Niech się bona nad dzieckiem zbytnio nie roztkliwia. Przy ubieraniu i rozbieraniu dziecka niech przestrzega skromności do ostatecznej, możliwie posuniętej granicy. O potrzebach naturalnych glośno nie rozmawiać. Niech bona wpaja $w$ dzieci uszanowanie dla wszystkich ludzi bez wyjqtku. Chwalić tylko dobre zachowanie dziecka. W stosunkach swych z domownikami i ze slużacymi bona powinna być lagodnq, nie uleglq, ale tez niezbyt poufata lub ulegla, w: W. Puffke, Zabawy, gimnastyka i pogadanki w szkólce freblowskiej. Poznań 1911, ss. 499-517.

${ }^{39}$ A. Sobolewska, $W$ sprawie wychowawczyń..., s. 6.

${ }^{40}$ Większość istniejących $\mathrm{w}$ analizowanym okresie kantorów stręczeń współpracowało z tego typu biurami za granica, bądź prowadziło tam własne biura i za ich pośrednictwem sprowadzało cudzoziemki bezpośrednio z Francji, Anglii czy Niemiec. Np. Kaucjonowane biuro nauczycielskie K. Sotkiewiczowej rekomenduje nauczycieli, nauczycielki i bony, a po zawiqzaniu osobistych stosunków w Paryżu, Genewie i Lozannie, może dostanczyć cudzoziemek różnych stopni wyksztalcenia pod gwarancja moralności, „Kłosy” 1889, nr 25; Koncesjonowane przez Wysokie c.k. Namiestnictwo biuro nauczycielskie Stefanii Lapiczów z Trembeckich Zwilling, Kraków, poleca [...] bony różnej narodowości tak z kraju jak $i$ wprost z zagranicy sprowadzanych, „Ilustracja Polska”, 1902, nr 51; Pierwszorzędne biuro pedagogiczne Leokadii Max poleca nauczycielki, nauczycieli, freblówki, cudzoziemki. Francuski sprowadza z wlasnego biura w Paryżu, „Świat”, 1909, nr 21; Kaucjonowane biuro nauczycielskie profesorowej Clavel w Warszawie, poleca nauczycieli, nauczycielki, wychowawczynie i bony. Korespondencje z Francja, Szwajcariq. Niemcami i Angliq, „Tygodnik Mód i Powieści" 1899, nr 39, s. 391; Pierwszorzędny kantor nauczycielski Zalęski w Warszawie, pośredniczy w umieszczaniu nauczycieli, nauczycielek, bon różnej narodowości $i$ takowe na żqdanie sprowadza z zagranicy, „Kraj” 1892, nr 2, s. 1; Biuro nauczycielskie Justyny z Jędrzejewskich Paulus, Wiedeń, poleca nauczycielki i bony narodowości polskiej, francuskiej, niemieckiej i angielskiej, „Kraj” 1893, nr 35, s. 29; Biuro nauczycielskie Z. Jasińskiej poleca nauczycieli, nauczycielki, bony, freblanki, ochroniarki. Sprowadza Angielki, Francuzki, Niemki z wlasnych biur zagranicznych, „Swiat” 1911, nr 26, s. 1.

${ }^{41}$ Poseł Prawdy w 1887 na łamach „Prawdy” opowiadal, w jaki sposób poszukiwał w Niemczech bony dla swych znajomych: Zamieścilem $w$ jednym $z$ saskich pism ogloszenie. Nazajutrz zbieglo się do mnie okolo stu różnych dziewczyn. Nieszczęśliwy, pomyślalem - co ja pocznę z tym zastępem, którq wybrać? Gdyby mi ktoś poradzil! Nie poradzil nikt - zadatkowalem najsympatyczniejszq, która okazala się dobrq, ale mogla być również zlodziejkq lub ladacznicq, Poseł Prawdy, Liberum Veto, „Prawda” 1887, nr 37, s. 440.

${ }^{42}$ Jak wspominała Janina z Puttkamierów Żółtowska: thusta, mala i okragla M-elle Francie to uniwersalna bona w gronie krewnych i przedtem opiekunka wuja Tonia Kieniewicza. Gniewala się latwo, byla were dyczkq $i$ znala historię wszystkich dworów i dzieci na Litwie wedle stopnia ich grzeczności, w: J. Z Puttkamerów Żółtowska, Inne czasy inni ludzie, Londyn 1959, s. 10.

${ }^{43}$ Np. Bona Francuzka lub znajqca dobrze ten jezyk, $w$ mlodym wieku, z moralnym wychowaniem i lagodnym charakterem, który by oprócz mówienia i pisania mogla udzielać i począlki innych nauk, potrzebna jest do panienki 6-letniej od 1 października, „Kurier Warszawski” 1850, nr 222; Bona mówiqca poprawnie po niemiecku potrzebna od zaraz, „Dziennik Kujawski” 1894, nr 63; Potrzebna jest bona w średnim wieku, dobrej konduity, posiadajaca doskonale polski, francuski, $i w$ części ruski, do 3 maloletnich panien, która by mogla w calym oznaczeniu opiekować się dziećmi jak matka, „Kurier Warszawski” 1850, nr 184; Potrzebna bona za Warszawe. Musi być inteligentnq, znać dobrze język ojczysty i niemiecki i być cokolwiek muzykalnq. pensja roczna 160 rubli, „Praca” 1988, nr 49; Potrzebna od kwietnia bona wydoskonalona w swym zawodzie, do trojga dzieci (dwa lata i bliźniqt rocznych), „Sztandar” 1911, s. 16. 
się polecenia i rekomendacje wystawiane bonom przez byłych pracodawców ${ }^{44}$. Również kobiety, chcące znaleźć posadę bony poszukiwały zatrudnienia tą samą drogą ${ }^{45}$.

W praktyce okazywało się, że większość bon sprowadzanych z zagranicy do kraju nie miała żadnego wykształcenia. Zdarzały się byłe kawiarki, pastuszki, kucharki, kelnerki, pokojówki, śpiewaczki kabaretowe, szansonistki, a nawet więźniarki, które za granicami kraju szukały lepszego losu i zarobku ${ }^{46}$. Jak były zatem w stanie wykształcić polskie dzieci bony o takim pochodzeniu społecznym, niełatwo się domyślić. Wystarczyło, jak wówczas praktykowano, że bona miała dobry akcent paryski lub berliński, zaś o stronę moralną już nie dbano ${ }^{47}$. Wạtpliwe nawet, czy język obcy którego uczyły, był czystym i wolnym od regionalizmów. Dokładną charakterystykę wykształcenia i przygotowania bon Francuzek zamieściła autorka o pseudonimie „I. Z.” na łamach „Przeglądu Pedagogicznego" 1890 r. Dane zgromadziła w kantorach stręczeń we Francji, wysyłających bony do Polski. Okazało się, że do kraju naszego trafiały zwykle kobiety niewykształcone, w najlepszym razie mające świadectwo z ukończenia szkoły początkowej (certificat d'études primaires), znakomita zaś ich większość umiała zaledwie czytać i nieortograficznie pisać ${ }^{48}$. Proste i niewykształcone, gdy przyjeżdżały na bony, pragnęły na obczyźnie uchodzić za kogoś lepszego, wyższego, nie lubiły powierzonych im dzieci i swojej pracy $^{49}$, a nawet liczyły na dobry i korzystny ożenek ${ }^{50}$. Za pośrednictwem „Przeglądu

\footnotetext{
${ }^{44}$ Np. Bona Francuska pozostajaca od 10 lat $w$ moim domu zaslugujaca na chlubna rekomendacje, poszukuje obowiqzku z placq 1000 franków rocznie, „Swiat” 1892, nr 44, nr 44.

${ }^{45} \mathrm{~Np}$. Osoba w średnim wieku, rodem z Królewca, mówiąca po niemiecku i po polsku, i znajqca się przy tym na krawieczyźnie, życzy sobie objać miejsce jako bona. Osoba ta posiada świadectwa, że bywala w obowiqzku po lat 6, „Kurier Warszawski” 1869, nr 87; Bona mloda, lubiaca dzieci, skromnych wymagan', posiadajqca świadectwa, poszukuje miejsca do dzieci od 2 do 7 lat, „Dziennik Kijowski” 1913, nr 45.

${ }^{46}$ Znam rodzine $w$ squsiedztwie, która przekonawszy się przypadkiem o artystycznych zdolnościach swej bony Niemki, ku wielkiemu swemu zdziwieniu dowiedziala sie, ie nim przybyla do ich domu, debiutowala na scenie w podrzędnym niemieckim teatrze, w: F. de Cez, Dobrze zrozumiane zycie. Z francuskiego dla naszych pań przelożyl ks. Aleksander M., Brody 1912, s.92; Ktöż to sq bony? Bony sq to zazwyczaj mniej więcej wysortowane $w$ kraju wlasnym osobniki, które za przybyciem do nas awansujq ze stanowiska np. bylych szansonistek, pokojówek itp. na stanowisko wychowawców naszych dzieci , w: A. Potocki, Stugi...,
} s. 101 .

${ }^{47}$ Ktöż zaręczy, że taka madamonsielle, czy fraulein nie byla $w$ swoim kraju kelnerkq $w$ restauracji czy śpiewaczkq w cafe chantante? Bardzo być może. Sa między nimi porzqdne, to nie ulega watpliwości, lecz, niestety, okazuje się to po kilku miesiqcach pobytu. A jeśli okaże się po kilku miesiqcach, ze bylo przeciwnie, któż zaplaci pokrzywdzonym rodzicom za te kilka miesięcy, jakie dzieci ich musialy być w niestosownym towarzystwie?, Prawdzic, Sprowadzanie bon Szwajcarek, „Prawda” 1900, nr 5, s. 125.

${ }^{48}$ I. Z. stwierdzała, że większość bon-cudzoziemek niewiele różniła się poziomem umysłowym od polskich pokojówek Gdyby przynajmniej pod względem moralnym dorównywaty one naszym Kasiom i Marcysiom, ale na nieszczęsicie stoja $a$ wiele niżej od nich, w: I. Z., Jakie bony otrzymujemy..., s. 52.

${ }^{49}$ Tak pisała o próżności prostych dziewcząt przybyłych z zagranicy do możnych domów Karolina Nakwaska: Dziewczyna, która by dobra być mogla bonq pod dozorem bacznej matki, obrócona do ushug dziecinnych, przybywajac w grono domowe, do stolu pańskiego przypuszczona, mademoiselle tytulowana, zostawiona próżnowaniu i dajaca nauki, których sama nie posiada, jakże może obowiqzki te nad jej zdolności dobrze wypelniać? Cóż się dzieje? Oto zamiast zobowiqzania jej sobie, psuje się ja, choćby dobrq byla, próżność jej glowę zawraca, dzieci jq nudzq, rada co prędzej opuścić dom, w którym jej stan pierwotny widziano i ta, która by byla użytecznq na niższym stanowisku, staje się ciężarem domowym, lub częstokroć ze zgorszeniem odchodzi!, w: K. Nakwaska, op.cit., s. 122.

${ }^{50}$ Wprawdzie we Francji była ogromna liczba wykształconych i dobrze przygotowanych pod względem pedagogicznym nauczycielek, które nie mogły znaleźć pracy, lecz ze względu na niskie wynagrodzenie nie 
Pedagogicznego" jedna $\mathrm{z}$ domowych nauczycielek przestrzegała matki przed oddawaniem dzieci $w$ ręce osób tak ograniczonych lub zdemoralizowanych, a zawsze niemajacych najmniejszego przygotowania pedagogicznego, jakimi sa niemal wszystkie nasze bony cudzoziemki $i^{5 !}$.

Nie można jednak zapominać, iż wśród bon cudzoziemek bywały i kobiety dobrze wykształcone, posiadające wszelkie pożądane przymioty ducha. Jak pisała autorka o pseudonimie I. Z., Niewatpliwie trafiaja sie i między bonami jednostki moralne, a nawet inteligentne $i$ względnie wyksztalcone, ale stanowiq one tak rzadkie wyjątki, że liczyć na nie można $z$ równq pewnościa jak na wygranq loteryjna ${ }^{52}$. Wobec licznych artykułów i głosów potępiających zwyczaj zatrudniania bon cudzoziemek, pojawiały się oczywiście i głosy w obronie tych zagranicznych wychowawczyń, należące głównie do matek, które zadowolone były ze swoich pomocnic w wychowaniu dzieci ${ }^{53}$. Niektóre matki zaprzeczały temu, by zagraniczne bony wywierały zły wpływ na dziecko, ponieważ zwykle to one - matki, zachowywały główny kierunek wychowawczy. Jak jednak mówiła praktyka, takich matek, które nadawałyby bieg procesowi wychowania dziecka nie było zbyt dużo, większość pozostawiała niemal zupełny wpływ na dziecko bonie, która, nie dość, że nie

przyjeżdżały one do Polski. Jedynie bardzo wysoka zapłata była w stanie nieliczne wyjątki sprowadzić do kraju, za: I.Z., Jakie bony..., op.cit., s. 52; identyczną opinię na temat bon cudzoziemek wyraziła „Biblioteka Warszawska", która podawała, iż we Francji jest bardzo dużo sumiennych, zdolnych i pracowitych nauczycielek, lecz po skończeniu szkoły pozostają one w kraju, gdzie niski poziom umysłowy ludności wymaga wielkiej ich liczby, albo jadą do Anglii, Niemiec czy Ameryki, gdzie otrzymują wysokie wynagrodzenie. Do kraju naszego zaś sprowadzane są tłumnie proste dziewki, o wątpliwej wartości moralnej, z wyksztalceniem ledwie elementamym, niewładające poprawnie nawet własnym językiem, za: Kronika Miesięczna, „Biblioteka Warszawska" 1892, t. 1, Warszawa, s. 183.

${ }^{51}$ Młoda Nauczycielka, Francuzo-muzykomania, „Przegląd Pedagogiczny” 1888, nr 10, s. 117.

52 I. Z., op.cit., s. 52.

53 Jak podają źródła pamiętnikarskie, bywały bony cudzoziemki, które okazały się być nie tylko dobrze wykształcone, ale miłe i sympatyczne. Zofia z Rodowiczów Iwanicka, mieszkanka Królestwa Polskiego, tak wspominała swoje bony cudzoziemki: Od dziecka byly w domu cudzoziemki do nauki języków. Gdy bracia byli mali, przebywala u nas panna Bodin, Niemka z Kurlandii, bardzo mila osoba. Gdy skończylam trzy lata, przyjechata do nas Francuska, panna Klementyna Chrecka, o polskim nazwisku, gdyż jej ojciec byl emigrantem we Francji. Przebywala u nas 5 lat i pozostawila po sobie najmilsze wspomnienia. Byla to osoba bardzo dobra, glęboko religijna, nadzwyczaj obowiqzkowa, sumienna, porzqdna, niemajaca w sobie nic z lekkomyślności Francuzek. Wychowanka Sacre Coeur w Paryżu (szkola dla dziewczqt prowadzona przez siostry zgromadzenia Najświętszego Serca Jezusowego zalożonego w 1800 roku we Francji), mówila ze świetnym akcentem, nauczyla nas znakomicie tego języka [...] Madameosielle Clemencie nauczyla mnie też systematyczności w drobiazgach życia codziennego, w: W. Rodowicz, S. Rodowiczowa, Z. z Rodowiczów Iwanicka, Tryptyk rodzinny. Dzieje rodziny Rodowiczów, Warszawa 1999, s. 69; O doskonałym wypelnianiu obowiązków bony, a także o serdecznym stosunku, jaki łączył bonę z podopiecznym, pisal zamieszkały w Warszawie Karol Mitkiewicz: W okresie przedszkolnym mialem do towarzystwa bonę, Amelię, mlodq, wesolq Wiedenkę, której też pod względem wychowawczym wiele mam do zawdzięczenia. Bona zabierała chłopca na spacery do Ogrodu Saskiego, do Łazienek, na lekcje gimnastyki, nauczyła go wielu różnych piosenek, a nawet pływania żabką. Piastunka tak przywiązała się do chlopca i jego rodziny, a także do Polski, że wkrótce lepiej mówiła po polsku, niż autor wspomnień po niemiecku, w: K. Mitkiewicz, Spojrzenia wstecz, Warszawa 1970, s.6; Podobnie Helena Anna Gayer, mieszkanka zaboru rosyjskiego wspomina bonę do dzieci, cudzoziemkę, która spędzila pod dachem jej domu 9 lat. Powierzone jej dzieci, kochała jak swoje własne, szczególnie te, które urodziły się podczas jej pobytu w domu pracodawców: Byla naszq kochanq domowniczkq, przyjaciólkq, dzielita z nami smutek i radość [...] zostala pochowana w naszym grobowcu rodzinnym. Rzadko się dzisiaj spotyka, by pracownik byl tak ogromnie przywiazany, a do tego bezinteresowny, w: H. A. Gayer, Z mojego życia. Wspomnienia z lat 1855-1914, Lódź 2003, s. 28. 
posiadała odpowiedniego przygotowania pedagogicznego, to przeniesiona $w$ nowe warunki życia, nie rozumiała wielu rzeczy, które powinny wejść w skład pierwszego wychowania polskiego dziecka ${ }^{54}$.

Zatrudnianie bon cudzoziemek na terenie ziem polskich powszechnie niemal odradzane było rodzicom już od końca XVIII $w^{55} \mathrm{i}$ aktualne pozostało do początków wieku $\mathrm{XX}^{56}$. Przyczyną był nie tylko brak wykształcenia i wątpliwe ich pochodzenie społeczne, ale i niemożność wpajania dzieciom uczuć patriotycznych przez takie wychowawczynie. Często bowiem owe cudzoziemki miały manię wyższości swojego kraju, a na wszystko co polskie patrzyły z pogarda ${ }^{57}$. Publicyści pedagogiczni zgodnie twierdzili, iż dziecko od najmłodszych lat powinno otaczane być atmosferą polskości, szacunku do wszystkiego co polskie. Bony cudzoziemki zaś, nie znające historii ani tradycji narodowych, nie były w stanie tym zaleceniom sprostać; co gorsze, sprawiały, iż dzieci często nie potrafiły poprawnie używać języka ojczystego ${ }^{58}$ !

\footnotetext{
${ }^{54}$ M. I., U początku. „Bluszcz” 1893/4, nr 2, s. 1.

55 Patrz np. Przedmowa do rodziców, w: M. Prokopowicz, Sposób nowy najlatwiejszy pisania i czytania razem dla panienek z przypisami dla nauczycielek, Kraków 1790.

${ }^{56}$ Pojawiały się jednak także głosy „za”, stwierdzające, iż zatrudnianie bon cudzoziemek jest bardzo pożyteczne i korzystne dla samych dzieci. Eliza Orzeszkowa twierdziła, że bony cudzoziemki powinny piastować dzieci od samego ich wyjścia $\mathrm{z}$ niemowlęctwa, gdyż nigdy dziecię z takq latwościq nie wprawi się w obca mowe, jak w tej pierwotnej porze swojego życia, a wczesne uczenie jezzyka obcego oszczędzi dziecku trudów i zmarnowanego na naukę czasu w przyszłości. Podkreślała ona jednak, że bony cudzoziemki sprawdzają się jedynie $w$ sytuacjach, gdy rodzice nie pozwalają by dzieci im powierzone zapomniały ojczystego języka, w: E. Orzeszkowa, Kilka slów o kobietach, Warszawa 1873, s. 179.

57 Bona cudzoziemka przynosi też zwykle ze sobq więcej lub mniej ukrywana pogardę dla obcego sobie kraju, która zostawia zawsze niezatarte ślady $w$ umyśle dzieci. W najlepszym razie nie może wpajać milości do wszystkiego, co swojskie, w: W. Marrene-Morzkowska, Jeszcze o bonach cudzoziemkach, „Tygodnik Ilustrowany" 1897, nr 25, Warszawa, s. 489; Dla Niemki wszystko np. co nie trqci Berlinem nie ma żadnej zgola wartości; dla Francuzki znów tylko paryska kawiarniana blaga przysiwieca; wszystkie więc zagraniczne te gusta wsiakaja $w$ rozwijające się umysly pupilków, wyrabiajqc w nich zawczasu obojętność dla wlasnego gniazda, w: J. Jeleński, op.cit., s. 1; Zagraniczne bony najczęśsiej pomiataly krajem, do którego ich tak niebacznie sprowadzono; a dzieci shyszaly od kolebki, ze pochodzq z narodu barbarzyńskiego, wpóldzikiego, ze ich wlasny język jest twardy, nieokrzesany, śmieszny nawet $i$ bezpożyteczny, skoro koniecznie od najpierwszego dzieciństwa innego uczyć się muszq, w: J. Olszyc, op.cit., s. 276; interesujący obrazek zaobserwował także Poseł Prawdy w ogrodzie botanicznym, w którym 6-letnia dziewczynka bawiła się pod opieką bony Niemki nad basenem. W pewnym momencie Niemka podeszła do dziecka i bez powodu zaczęla bić i szczypać dziewczynke, wołając przy tym ze złością: du verfluchtes polonisches Schwein! w: Poseł Prawdy, Liberum Veto. Polowanie na rozkoszne dziewczatka, „Prawda” 1883, nr 30, s. 357.

${ }^{58} \mathrm{~W}$ ten sposób, domowymi środkami, wynaradawiaja rodzice wlasne dzieci, odsuwając je od obowiqzków obywatelskich. Zapominaja o tym, że zrozumienie obcych języków staje się latwiejszym i pożyteczniejszym wtedy, gdy dziecko najpierw we wlasnym mysileć się nauczy. Przeklęta ta moda cudzoziemszczyzny, której po tylu bolesnych doświadczeniach pozbyć się nie możemy, charakteryzujqca Polaków wylqcznie, bo nie ma innego narodu, zaczynającego wychowanie swych dzieci od oduczania ich wlasnego języka", w: Poklosie, „Kłosy” 1877, nr 621, s. 338; smutny rezultat wychowania pod kierunkiem cudzoziemek podaje „Biesiada Literacka”. Syn bogatych rodziców, który po stracie majątku zgłosił do jednej z instytucji prywatnych z prośbą o posadę, nie otrzymał jej, ponieważ nie umiał pisać po polsku. Posiadając dużo wiadomości, mogqc uchodzić za Francuza, Niemca lub Anglika, krztusi się kiedy musi mówić po polsku, a o ortografii nie ma pojęcia. Czemuż to mamam i papa nie pamiętali o tym, ze sq ojcem i matka polskiego dziecięcia?, w: Raptular Tygodniowy, Za winy matki, „Biesiada Literacka 1886, nr 10, s. 155.
} 
Sprowadzanie bon cudzoziemek wynaradawiających polskie dzieci krytykowano na łamach prasy we wszystkich trzech zaborach ${ }^{59}$. W Wielkopolsce szczególnie krytykowano zatrudnianie bon Niemek, zalecając zastąpić je Polkami, które znały doskonale język niemiecki, ale poza godzinami lekcji rozmawiały $\mathrm{z}$ dziećmi $\mathrm{w}$ języku polskim, a poza tym mogły nauczyć je także podstaw historii, literatury i geografii ojczystego $\mathrm{kraju}^{60}$. Jak wynika z analizy źródeł, bony Niemki cieszyły się najgorszą opinią teoretyków nauczania nie tylko w zaborze pruskim, ale we wszystkich trzech zaborach ${ }^{61}$. Powszechnie odradzano zatrudnianie dla nauki jezzyka niemieckiego rodowitych Niemek, słynących ze swojej wyniosłości i złośliwości wobec polskich dzieci ${ }^{62}$, radząc, iż, by dzieci wasze umialy dobrze po niemiecku, to znajdziecie w Gnieżnie, Poznaniu itd. zawsze pannę z dobrego, uczciwego domu, która chętnie podejmie się obowiqzku ich

${ }^{59}$ Za przyczynę wynarodowienia dzieci uważano nie tylko nauczanie języka obcego, lecz także brak troski matek o wychowanie wlasnych dzieci i pozostawianie ich pod zupelnym dozorem i wpływem cudzoziemek: Jeśli matka każe się Francuzce lub Niemce wyręczać nie tylko przy nauce języków, ale i serdecznych rozmowach, i przy pacierzu, $i$ w czasie choroby dziecka, i tym podobnych okolicznościach, $w$ których serce gra glównq rolę, to najlepsza bona mimowolne dziecko wynarodowi i pod dachem naszym wychowa cudzoziemca, w: K. Oluliczowa, $O$ naszych bonach. „Biesiada Literacka” 1885, nr 20, s. 315.

${ }^{60}$ Maria Ilnicka w „Bluszczu” bardzo wnikliwie rozpatruje sprawę bon Niemek, które, jako przedstawicielki narodu zaborcy, nie mogły być dobrymi bonami dla polskich dzieci. Nazywa zatrudnianie takich wychowawczyń anomaliq $i$ sprzecznościq najwyższq. Ze względu na uczucia patriotyczne, które w dziecku od malego ksztalcić należy, sympatycznq i mila być ta bona nie może, nie powinna [...] Zastapienie bony cudzoziemki rodaczkq byloby rzecza niezmiernie ważq w ekonomii naszej moralnej, w: M. Ilnicka, Do rodziców, op.cit., s. 187; Podobne zarzuty wobec bon Niemek stawia „Glos Wielkopolanek”: Czy bona Niemka nauczy dzieci wasze czytania i pisania polskiego, co powinno nastapić ju̇ przed zaczeciem odwiedzania szkoly? Czy Niemka nauczy je liczyć i rachować po polsku? Czy Niemka umie dzieciom waszym opowiadać polskie baśnie, bajki, wiersze, legendy o bohaterach $i$ królach narodowych? Czy ona będzie dzieci wasze uczyla o ziemi i o dziejach polskich? Czy bona Niemka zaśpiewa z dziećmi waszymi piosenkę i pień polska? Czy ona wzbudzać będzie w dzieciach waszych, w obcym języku, wiarę $i$ milość do Boga $i$ bliźniego? Wreszcie, czy jesteście pewni, że Niemka, choć mimowolnie, nie będzie szpiegiem w domu waszym? Odpowiedzcie laskawe panie na to $w$ duszy waszej, a przyznacie sluszność, iż należy zamiast opiekunek Niemek, Francuzek, Angielek, brać do dzieci polskich tylko bony Polki - i swoim tylko chleb dawać, bo taki jest obowiqzek narodowy!, w: J. S-k, Bony niemieckie, „Glos Wielkopolanek” 1909, nr 17, ss. 5-6; Język niemiecki istotnie jest potrzebny, ale czyż do przyswojenia go potrzeba rodowitej Niemki? Wiemy wszyscy, że paplanie dziecka $z$ bonq jest niedostateczne do celów praktycznej nauki, gdyz przyswoi sobie tylko tym sposobem elementarne wyrazy i zdania. Przeciez, jeśli o to chodzi troskliwym rodzicom, nie brak przecież Polek, posiadajqcych język niemiecki doskonale, który by mogly go udzielać, rzecz dziwna, iż rzecz tak prosta przypominać trzeba, w: W. Marrene-Morżkowska, Nieposzanowanie samych siebie, w: $Z$ tygodnia na tydzien், „Tygodnik Ilustrowany" 1901 , nr 27, s. 519.

${ }^{61}$ Jak wspominała Maria Czapska, gdy w domu pojawiła się Niemka, dziadek drażnił się z nią przy stole i pomstowal na Bismarcka, co powodowało oburzenie i płacz u bony, w: M. Czapska, Europa w rodzinie. Czas odmieniony, Kraków 2004, s. 96.

${ }^{62}$ Przykładów na, jak je nazywano, „bony-hakatystki” nie brakowało. Prasa rozpisywała się na ten temat, by nie wspólczuć w zmartwieniu, ale przeciwnie, odstręczyć drugich od blędu zatrudnienia bony Niemki, w: Z Warszawy, „Biesiada Literacka 1901, nr 34, s. 143; W jednym z listów nadesłanych do redakcji „Gazety Warszawskiej" czytelnik pisze, iż hakata ma swoją 'sekcję kobiecą', do której zaliczają się frauleiny, czyli bony Niemki, rozrzucone na posadach w różnych częściach kraju. Autor listu, zamieszkały w Królestwie Polskim, zatrudnił taką bonę, która nosiła polskie nazwisko Berty Sadowskiej, była katoliczką udawala przyjaciółkę rodziny, a przed dziećmi obdarzała ją epitetem „polnisches vieh” (polskie bydło). Podczas wyjazdu do Kołobrzegu, przebywając „wśród swoich” traktowała swych pracodawców z góry, za co zostala zwolniona. Zerwanie umowy z boną o polskim nazwisku, a duszy krzyżackiej, kosztowało autora listu 500 marek, w: ibidem. 
uczenia $^{63}$. Taką właśnie bonę wspomina mieszkający w Lublinie Stanisław Arct, którego rodzice bardzo dbali, by dzieci od najmłodszych lat opanowywały języki obce. Do języka niemieckiego zatrudnili fraulein Jankę, Poznaniankę $\mathrm{z}$ dobrym niemieckim akcentem ${ }^{64}$. Poszukiwania przez rodziców bon Polek, ze znajomością języka niemieckiego potwierdzają ogłoszenia, zamieszczane na łamach wychodzących pod zaborem pruskim czasopism, np. Znajdzie miejsce od lipca bona Polka mówiqca dobrze po niemiecku, na $100-120 \mathrm{rubli}^{65}$.

Innym zarzutem tak powszechnego zatrudniania bon cudzoziemek było zbytnie obarczanie pamięci dziecka wieloma słówkami i zwrotami obcojęzycznymi, podczas gdy jak radzono na łamach ówczesnych czasopism - powinno ono najpierw dobrze poznać mowę ojczystą ${ }^{66}$. Najbardziej krytykowane było zatrudnianie kilku cudzoziemek jednocześnie, dla nauki kilku języków. Umysl, który od tylu i tak wczesnych lat zmuszony byt pracowac tak intensywnie, jest niedorozwinięty, lub w najlepszym razie mniej podatny do szybkiego rozwoju. Język ojczysty u takiego dziecka jest ubogi i pokaleczony ${ }^{67}$. Jak wspominała Maria Małgorzata z Radziwiłłów Franciszkowa Potocka (zamieszkała w Prusach), od najmłodszych lat zatrudniono dla niej i rodzeństwa bony Niemki i Francuzkę, a ponadto uczono oczywiście języka polskiego. Skutki takiego nauczania były opłakane: Pierwszym rezultatem było, że mieszaliśmy trzy języki $w$ straszliwy sposób ${ }^{68}$.

Zalecano przyjmowanie cudzoziemek dopiero do starszych dzieci, które mają już dobrze opanowany język ojczysty i na jego bazie uczyć się będą języka obcego, co przyjdzie im $\mathrm{z}$ łatwością i nie będzie groziło myleniem pojęć i słów w obu językach ${ }^{69}$. Lepiej też było wybrać jeden język i przez kilka lat kształcić go aż do perfekcji, niż co kilka lat zmieniać bony cudzoziemki, by nauczyć dzieci mówić kilkoma językami, za to bardzo pobieżnie ${ }^{70}$.

\footnotetext{
${ }^{63}$ J. S-k, op.cit., s. 17.

${ }^{64}$ S. Arct, Okruchy wspomnien, Warszawa 1962, s. 106.

65 „Dziennik Kujawski” 1894, nг 105.
}

${ }^{66}$ Patrz J. Jeleński, op.cit., s. 2; Kto zaś dziecko już w zaraniu tworzenia jego mowy ojczystej chce równocześnie drugiej mowy nauczyć, ten szkodzi mózgowi dziecięcemu. To też najznakomitsi pedagodzy stawiaja na pierwszym miejscu zasadę: Naucz dziecko najpierw dobrze języka ojczystego, abyś na tej podstawie mógl dalej budować, w: J. S-ka, Bony niemieckie, op.cit., s. 6; Mala Zosia, która w wieku 3 lat zna określonq liczbę slów $i$ ma pewien zasób pojęć (bardzo skromny), pewnego dnia zmuszona jest do porozumiewania się z cudzoziemkq. która przydana jej zostala na calodziennq towarzyszkę. Jej dalszy rozwój umyslowy zostaje chwilowo powstrzymany, albowiem musi ona caly swój zasób wiadomości i pojęć niejako przetlumaczyć na obcy język, w: A. Sobolewska, Kiedy należy brać cudzoziemkę, „Dziecko” 1913, z. S, ss. 255-256; patrz też: Kronika dzialalności kobiecej, „Bluszcz” 1892, nr 46, s. 365.

${ }^{67}$ A. Sobolewska, op.cit., s. 256.

${ }^{68}$ W: M M. z Radziwiłłów Franciszkowa Potocka, op.cit., s. 97; Cześć rodziców, jak wskazują źródła pamiętnikarskie, świadoma była faktu szkodliwości zbyt szybkiego obarczania umysłu dziecka obcojęzycznymi zwrotami. Jak donosił $w$ jednym $z$ listów do żony Teodor Toeplitz (zamieszkały w Królestwie Polskim), poszukujący bon dla swych dzieci: Uczyć Lolka bez Jadzi po francusku byloby trudno, a dla niej stanowczo jest za wcześnie, lepiej więc raczej, by on zaczal o rok później, aniżeli ona by za wcześnie pamięć napelniala mnóstwem slów [...] Nie bardzo bym chcial Niemki w domu. Nie chcialbym też krzywdzić Tusia, każqc mu za wcześnie po niemiecku gadać. Niech mu dziób po polsku rośnie, w: K. T. Toeplitz, Ksiqżka mojego ojca, Warszawa 2004, s. 258.

${ }^{69} \mathrm{~J}$. Olszyc, op.cit., s. 276.

${ }^{70}$ A. Sobolewska, Kiedy należy brać, s. 257; Jeśli chcemy być logicznymi, zaczekajmy z nauka języków do siódmego lub ósmego roku, a wtedy uczmy tylko po jednym języku na raz, w: Listy mojej babki, "Biesiada 
Wobec licznych zarzutów stawianych bonom cudzoziemkom, a także wobec poglądu, mówiącego o szkodliwości zbyt wczesnego obciążania dziecinnego umysłu kilku naraz językami, odbywajacemu się ze szkodq wladz innych i naruszaniu równowagi inteligen$c j i^{71}$, coraz powszechniejsze stały się postulaty zatrudniania bon Polek ${ }^{72}$, które to postulaty, choć pojawiały się przez cały wiek XIX, nie odnosiły znaczących skutków. Szczególnej jednak siły nabrały one w ostatnim 20. XIX wieku. Głosy takie słyszalne były szczególnie w zaborze rosyjskim, gdzie najwięcej wydawano pism, gazet i publikacji zajmujących się problematyką wychowania i nauczania dzieci, w tym także problematyką bon, lecz i w pozostałych zaborach krytykowano bony cudzoziemki i zalecano zatrudnianie w ich miejsce Polek.

W 1875 r. „Gazeta Polska” wysunęła projekt dotyczący bon Polek ${ }^{73}$. Projekt ten był bardzo prosty, a dotyczył odejścia od edukacji cudzoziemskiej na rzecz poprawnego i gruntownego uczenia dzieci języka ojczystego. Bon Polek nie było jeszcze w latach 70 . XIX w. dużo, ponieważ dotqd $w$ bony zaopatrywaliśmy sie jedynie za granica, a to wyrobilo stagnacje produkcji krajowej ${ }^{74}$. Jak donosił Jan Jeleński w 1875 r., nieliczne bony Polki wobec panującej ,zagranicomanii” nie miały ani zbyt dużego powodzenia, ani poszanowania ${ }^{75}$. Sytuacja ta $\mathrm{z}$ czasem uległa zmianie, i po upływie dwóch zaledwie dziesięcioleci Jadwiga Unszlichtówna pisała: Tak $z$ Warszawy, jak z prowincji dochodza nas liczne zapotrzebowania bon, które by znaly zajęcia $w$ rodzaju freblowskich, a przy tym byty Polki ${ }^{76}$. Cudzoziemki jak się okazuje wyszły z mody, a opinia ich tak nadszarpnięta, ze trzeba niemalo cywilnej odwagi, by powierzyć im kierownictwo dzieci $i^{77}$. Wobec rosnącego zapotrzebowania na bony Polki, Jan Olszyc apelował do kobiet, które starały się o posady nauczycielek domowych, a ich nie otrzymywały z powodu zbyt niskich kwalifikacji, by decydowały się na podjęcie pracy w roli wychowawczyń do młodszych

Literacka" 1890, nr 48, s. 348; W. Marrene-Morzkowska dowodziła także, że język, którego uczyła ją w dzieciństwie bona, a którego nauka nie była kontynuowana, zostaje zapomniany. Ona sama, będąc 4-letnią dziewczynka, mówila biegle po francusku, po czym, gdy przestała się uczyć tego języka, zupełnie zapomniala nawet podstawowe zwroty, w: W. Marrene-Morzkowska, Jeszcze o bonach cudzoziemkach, „Tygodnik Ilustrowany" 1897, nr 25, s. 489.

71 J. Olszyc, op.cit. s. 275.

${ }^{72}$ Nie myśle bynajmniej zaprzeczać potrzeby nauki obcych języków - pisał Jan Olszyc - przeciwnie, potrzeba ta wzrasta w miare rozwoju cywilizacji; żqdam tylko, aby dzieci najprzód uczyly się myśleć i mówić rodzinnq mowq, azeby pierwsze osoby, które je otaczajq, były tejże samej narodowości, a to przynajmniej do sześciu lat wieku, w: J. Olszyc, op.cit., s. 276.

${ }^{73}$ Projekt ten przedstawiono w trzech artykułach wstępnych „Gazety Polskiej” (1875, nr 58, 63 i 64); patrz też Bolesław Prus, Kroniki. Wybór. Tom III - 1875-1900, wyboru dokonał, wstępem i przypisami opatrzyl Stanisław Fita, Warszawa 1987, ss. 24-25.

${ }^{74}$ J. Olszyc, op.cit., s. 276.

${ }^{75}$ Wobec szerokich prerogatyw, jakimi lada pokojówka zagraniczna u nas się cieszy, bony natomiast Polki, chociażby z lepszym nawet wychowaniem i uzdolnieniem, sq traktowane jak, ,zwyczajne zera" jak wszystkie inne najzwyczajniejsze pokojowe czy kuchenne „shużce”, J. Jeleński, op.cit., s. 2.

${ }^{76}$ Świadczą o tym pojawiające się coraz częstej w prasie ogłoszenia rodziców, poszukujących właśnie bon Polek, np. Potrzebna jest bona Polka w Nowogrodzie do dwojga dzieci: chlopczykowi 4, dziewczynce 3 lata, „Kraj” 1892, nr 7, s. 26; Potrzebna jest bona Polka, wynagrodzenia 100 rs. rocznie, „Kraj” 1892, nr 17, s. 28; Potrzebna bona Polka, lagodna i kochajaca dzieci, z szyciem, do jednej dziewczynki 5 lat, konieczna dobra rekomendacja, „Kraj” 1900, nr 35.

${ }^{77}$ J. Unszlichtówna, Bony Polki, „Przegląd Pedagogiczny” 1890, nr 9, s. 97. 
dzieci $^{78}$. Zatrudnianie bon Polek opłacalne było także ze względów ekonomicznych. Sprowadzenie bowiem bony cudzoziemki, a także zapłacenie jej według waluty kraju z którego pochodziła, czyniło zatrudnienie jej bardzo kosztownym. Poszukiwanie bony w rodzimym kraju i płacenie jej według krajowej waluty było znacznie tańsze i pozwalało większej liczby rodzin na taki wydatek ${ }^{79}$.

By jednak bony Polki spełniły oczekiwania rodziców co do właściwej opieki nad dziećmi, konieczne było, by miały odpowiednie w tym kierunku przygotowanie. Dlatego też, szczególnie na terenie Królestwa Polskiego, wysuwano projekty kształcenia bon, polegające na odpowiednim przygotowaniu teoretycznym i praktycznym. Praca teoretyczna polegać miała na zdobyciu wiadomości ogólnych z zakresu nauk przyrodniczych, języka polskiego, historii powszechnej i krajowej, higieny i pedagogiki (w zakresie elementarnym), a także wiadomości specjalnych, obejmujących sposoby pielęgnowania oraz zabawiania i zajmowania się dziećmi. Zaraz za nauką teoretyczną iść miała nauka praktyczna, a wraz z nią poznanie zamiłowań i potrzeb dzieci ${ }^{80}$. Wkrótce też powstawać zaczęły pierwsze prywatne szkółki freblowskie, zwane ogródkami, przy których, po uzyskaniu od władz odpowiedniego pozwolenia, można było nauczać metody freblowskiej te kobiety, które kształcić się chciały na bony. Szkół takich, szczególnie w końcu XIX i początku wieku XX, powstawało coraz więcej. W ogłoszeniach prasowych pojawiały się liczne

\footnotetext{
${ }^{78} \mathrm{Czyz}$ nauczycielki narażone na upokorzenie będace udzialem każdej nieudolności, nie uczyniłyby stokroc lepiej, gdyby nie pnqc się na stanowisko nieodpowiednie, przyjmowaly skromniejsze a równie pożyteczne zajęcie bony, dla którego bytyby wlaśnie odpowiednie?, w: J. Olszyc, op.cit., s. 276; podobnie pisala w 1885 r. Krystyna Okuliczowa, która stwierdzała, iż nauczycielek początkowych jest tak wiele, iż część $z$ nich nie może znaleźć posady; gdyby więc te kobiety podjęły się zajęcia bony: ani moralnej, ani materialnej nie poniostyby straty, choć może cierpialaby na tym zrazu milość wlasna, w: K. Okuliczowa, op.cit., s. 315; również za takim projektem opowiedziała się Feliksa Eger: Osoby niewyksztalcone specjalnie, ani też dostatecznie obeznane z zasadami pedagogiki, nieposiadajqce nauk w zakresie wyższym, a jednak majqce instynkt potrzebny do rozbudzenia życia i nadania wlaściwego kierunku mlodej roślince, niech nie dażq do miana nauczycielek, [...] a jako bony dokaża bardzo wiele i stanq się wielce użytecznymi, w: F. Eger, Slówko o obowiqzkach rodziców i nauczycielek w prowadzeniu dzieci, „Kronika Rodzinna” 1874, nr 12, s. 192.

${ }^{79}$ Jak pisała Maria Ilnicka, wobec kilku tysięcy bon cudzoziemek, zatrudnionych w polskich rodzinach, zastapienie ich bonami Polkami: spowodowaloby znalezienie szerokiego pola dla pracy na chleb, a zarazem pracy wielce pożytecznej $i$ odpowiadajacej kobiecie pod względem wszelakim. Powtarzam też, że należy pracownicom naszym zdobyć sobie to stanowisko, które jest nie tylko polem zarobku, ale i zaslugi obywatelskiej, przez usunięcie cudzoziemek, w: M. Ilnicka, Do rodziców, op.cit., s. 187; Identyczny apel skierowal do rodziców Prawdzic: Nie sprowadzajcie nauczycielek z zagranicy, dając przy tym zarobek swoim pracownicom, a zarówno oszczędzicie wlasny grosz, jak i podźwigniecie z ubóstwa legiony biednych kobiet Polek. Bo przecież tyle nauczycielek, sumiennych pracownic na ciężkim polu pedagogicznym poszukuje chleba, tyle ich $z$ nędzy prawie przymiera!, w: Prawdzic, op.cit., s. 125.

${ }^{80} \mathrm{~J}$. Unszlichtówna, op.cit., s. 98; W. Marrene, O utworzenie zakladu wychowawczego dla bon, w: Kronika Tygodniowa, ,Tygodnik Ilustrowany” 1883, nr 22, s. 346; Bona wyksztalcona pedagogicznie do swego zawodu, rozumiejaca na tej podstawie nature dziecka, musi z konieczności lepiej niż cudzoziemka, niemajaca żadnego wyksztalcenia pedagogicznego $i$ posiadajaca tylko język obcy $i$ to nie niepoprawnie, wywiqzać się z zadania swego - pisano, w: Kronika Działalności Kobiecej, „Bluszcz” 1893, nr 13, s. 103; Jak radziła Maria Ilnicka: Bonom Polkom trzeba odpowiednio sie uzdolnić, $i$ w kantorach stręczen zapisywać się wyraźnie jako bony, co oznacza osobe wyksztalconq wyżej niż prosta piastunka, osobe ze znajomościq metody pogladowej $i$ wspierajacymi ja wiadomościami. Powinna wprowadzać $w$ umysl dziecka pewne elementarne wiadomości o świecie $w$ sposób, który się zowie metoda freblowska, a dziecku nieco starszemu dać w bajce, w historyjce opowiadanej coś z pierwszej wiedzy geograficznej, historycznej. w: M. Ilnicka, Do rodziców, op.cit., s. 187.
} 
oferty nowych szkół i kursów, kształcących młode dziewczęta na wychowawczynie ${ }^{81}$. Nauka trwała zwykle od 6 miesięcy do 2 lat, a programy szkół zależne były od osób je prowadzących. Zwykle obejmowały one podstawowe wiadomości z zakresu nauk przyrodniczych, higieny, języka polskiego i pedagogiki, połączone z praktyczną nauką metody Froebla. Po ukończeniu kursu uczennice otrzymywały świadectwa i patenty. Wymagane było odpowiednie wykształcenie kandydatek, zwykle znajomość wiadomości z zakresu szkoły elementarnej. Za naukę trzeba było płacić, a opłaty pobierano zazwyczaj co miesiąc. Do szkoły bon przyjmowano tylko kobiety religijne, dobrych obyczajów, pilne i lagodnego charakteru. Tylko takie bowiem uczennice wdroża się $w$ obowiazki wymagające troskliwości, rozsqdku i zarazem serca ${ }^{82}$. Najwięcej tego typu szkół powstało $\mathrm{w}$ Warszawie ${ }^{83}$. Jak podaje Bella Sandler, pierwsze kursy freblowskie, przy założonym przez siebie pierwszym w kraju ogródku freblowskim, otworzyła już w 1869 roku Teresa Mleczko ${ }^{84}$. Pod koniec XIX stulecia w Warszawie istniało już kilkadziesiąt kursów dla bon i ochroniarek ${ }^{85}$; zakładano je także i w in-

${ }^{81} \mathrm{~Np}$. Kursy pedagogiczno-freblowskie Bronislawy Gerlach-Stopczyk, Hoża 64 w Warszawie, dla freblanek, ochroniarek, bon wychowawczyń. Gimnastyka, śpiew, rysunek, malarstwo. Sztuka stosowana z uwzglęnieniem rzemiosl kobiecych. Po ukonczeniu patenty z prawami. Przy szkole pensjonat, „Świat” 1911, nr 35, s. 230; Kursy Pedagogiczno-freblowskie Sqchockiej dla freblówek, ochroniarek, bon, wychowawczyń, krój, szycie, guzikarstwo, koszykarstwo, slojd. Konwersacja francuska, niemiecka. Po ukończeniu kursów patenty z prawami, „Swiat” 1911, nr 36, s. 26; Kursy pedagogiczno freblowskie Jadwigi Chrzaszczewskiej dla nauczycielek, ochroniarek $i$ bon. Gimnastyka, slojd, rysunek. Po ukończeniu świadectwa i posady. Aleje Jerozolimskie nr 2l, ibidem; Szkola ochroniarek Wiktorii Jędryczkowskiej. Kursy pedagogiczno-freblowskie dla nauczycielek wychowawczyń, slojd, koszykarstwo, po ukończeniu świadectwa, posady, „Bluszcz” 1907, $\mathrm{nr} 47$, s. 522; Kursy pedagogiczno-freblowskie ze slojdem, gimnastyka $i$ rysunkami dla nauczycielek $i$ bon Jadwigi Borowskiej, Wspólna 20. Pensjonat. Po ukończeniu świadectwa, posady, lekcje „Bluszcz 1907, nr 34, s. 378; Zaklad freblowski Janiny Anders, Wlodzimierska 19, Kursy dla bon i nauczycielek, „Tygodnik Ilustrowany" 1901, nr 33, Kursy freblowskie dla wychowawczyń w zakladzie Z. Grabowskiej, Sienna 8, Swiadectwa, posady, „Tygodnik llustrowany” 1901, nr 33; Freblowski zaklad, szkola freblanek, ochroniarek z gimnastyka rytmiczna Turańskiej, Warszawa, Szpitalna 6, wydaje uczennicom świadectwa i posady, „Przyjaciel Dzieci" 1912, nr 38, s. 455.

${ }^{82}$ Raptularz powszechny, „Biesiada Literacka” 1892, nr 9, s. 139

${ }^{83}$ Jak przestrzegała w 1893 r. Zuzanna Morawska, analizując liczbę coraz to nowych powstających w Warszawie szkół i zakładów freblowskich, nie należało doprowadzić do powstania przesadnej ich liczby, gdyż ksztakconymi w nich freblankom grozić będzie w przyszłości konkurencja i bezrobocie. Szkoły freblowskie sq prawdziwym dobrodziejstwem, ale powstaja corocznie tak, że na każdej ulicy można czytać obwieszczenia $o$ dwóch lub trzech tego rodzaju zakladach. Ostrzegamy jednak szanowne kierowniczki, że hiperprodukcja jest już bardzo bliska, w: Z. Morawska, Naśladownictwo, „Tygodnik Ilustrowany” 1893, nr 159, s. 19.

${ }^{84} \mathrm{~B}$. Sandler, Wychowanie przedszkolne $i$ ksztalcenie wychowawczyń $w$ Krölestwie Polskim, Wrocław-Warszawa-Kraków 1968, s. 68-75; zakład Teresy Mleczko przysłużył się spoleczeństwu nie tylko z powodu pierwszego ogródka freblowskiego, ale także właścicielka zajęla się dokształcaniem bon i nauczycielek domowych, przez organizację różnego rodzaju odczytów pedagogicznych. Np. 1881 r. w szkole p. Mleczko serię 12 wykładów o metodzie poglądowej, wraz z warsztatami i pokazami praktycznymi zajęć poglądowych przeprowadził Adolf Dygasiński, Poklosie, „Kłosy” 1881, nr 821, s. 187.

${ }^{85}$ W. Osterloff, O ksztalceniu umyslowym dzieci w okresie przedszkolnym, „Przegląd Pedagogiczny” 1896, nr 18, s.325; W 1890 r. p. Roszkowska otrzymała koncesję na zakład bon i piastunek z metoda freblowska, Z objawów życia, „Życie” 1890, nr 36, s. 639; w 1892 r. p. Kazimiera Łęcka założyła szkołę piastunek i bon na podstawie metody freblowskiej (kurs nauki trwał 2 lata) Kronika Działalności Kobiecej, „Bluszcz” 1892 , op.cit., s. 365 , w tym samym roku p. Zofia Duszyńska i W. Wernerowa założyły taka szkołę, kształcąca piastunki i bony, w której nauka trwała dwa lata, a obejmowała kształcenie się w metodzie Froebla, a także nauczanie czytania, pedagogikę, higienę i dietetykę dziecinną a także wiadomości z domowego 
nych miastach ${ }^{86}$. Przy szkołach froeblowskich w Warszawie istniały biura nauczycielskie, które zajmowały się pośredniczeniem w zatrudnianiu wykształconych „u siebie” bon feoeblanek, np. Biuro nauczycielskie J. Jahołkowskiej, Marszałkowska $143^{87}$, Biuro nauczycielskie Felicji Ginejko przy zakładzie freblowskim Jadwigi Chrząszczewskiej w Warszawie, Nowy Świat 21, Biuro nauczycielskie Jadwigi z Kellerów Bem, Senatorska 11 , przy zakładzie freblowskim M. Keller ${ }^{88}$.

W Galicji również istniał zakład, który kształcił bony i wychowawczynie małych dzieci. Był to Zakład Kórnicki hrabiny Zamoyskiej w Zakopanem, mający charakter szkoły pracy domowej. Powstał on w Kómiku, w Poznańskiem, lecz prześladowany przez władze pruskie przeniesiony został do Zakopanego. Do szkoły tej przyjmowano dziewczęta, które ukończyły szkołę ludową bądź pensję, a pragnęły przysposobić się do wszelkich obowiązków kobiecego życia. Szkoła posiadała 3 kursy: I oddział - dla panienek z możnych domów, chcących jedynie wprawić się w ogólne pojęcie o gospodarstwie, gdzie nauka trwała 1 rok; II oddział - przeznaczony dla panienek ze średnich warstw, którym praca własnych rąk mogła okazać się przydatna do prowadzenia i utrzymania domu, nauka trwała od 1 do 3 lat; III oddział - przeznaczony dla dziewcząt z klas uboższych, które własnoręcznie prowadzić musiały całe gospodarstwo domowe, a często shużyły w bogatych domach. Tu nauka trwała od 3 do 5 lat i była najgruntowniejsza. Z tego właśnie III oddziału rekrutowało się najwięcej przyszłych bon i piastunek dzieci. Obok prowadzonych w szkole, w zależności od poziomu intelektualnego dziewcząt w danym oddzia-

gospodarstwa. Do działu piastunek przyjmowano dziewczęta 17-letnie, moralnie prowadzące się, posiadajace ukończone dwuklasowe szkółki miejskie. Opłata miesięczna w oddziale bon wynosiła 5 rs., zaś w oddziale piastunek 3 rs., w: Kronika Dzialalności Kobiecej, „Bluszcz” 1892, nr 10, Warszawa, s.79; Zofia Grabowska przy swojej szkółce freblowskiej założyła szkole bon i niań, której program obejmował zapoznawanie uczennic $z$ poźytecznymi zabawami i zajęciami dzieci od lat 4 do 7 , takimi jak: wycinanie z papieru, struganie z drewna, lepienie z gliny, plecenie, rysunki początkowe, szycie, krój, naprawianie bielizny itd., w: Kronika Działalności Kobiecej, "Bluszcz” 1892, nr 31, s. 240; w 1893 r., szkółka p. Ludwiki Jahołkowskiej w Warszawie, przy ulicy Wspólnej 40, również otrzymała zgodę na prowadzenie kursu dla bon. W programie szkoły byly: praktyczne wskazówki obchodzenia się z dziećmi, zasady higieny, nauka gimnastyki pokojowej i ogrodowej, robótek ręcznych, zbierania zielników, hodowli roślin pod gołym niebem i w pokoju, Z Warszawy, „Biesiada Literacka" 1892, nr 38, s. 178. Szkoła Jahołkowskiej cieszyła się bardzo dobrą opinią i powodzeniem, a przy tym osiagała sukcesy. Jak donosił „Kraj” kursy freblowskie dla bon i nauczycielek w Zakladzie Ludwiki Jaholkowskiej, nagrodzone medalem srebrnym na wystawie higienicznej 1896 roku,
„Kraj" $1887, \mathrm{nr} 36$, s. 28 .

${ }^{86} \mathrm{~Np}$. w 1902 r. przy żeńskim zakładzie naukowym Anny Jastrzębskiej w Rydze również powstał kurs dla bon, „Przyjaciel Dzieci” 1902, nr 34.

${ }^{87}$ Pierwszorzędne nauczycielskie biuro Jadwigi Jaholkowskiej, bylej nauczycielki II gimnazjum poleca: nauczycielki, nauczycieli, cudzoziemki, bony Polski, oraz freblanki z zakladu Ludwiki Jaholkowskiej, "Tygodnik Ilustrowany" 1901, nr 15; Od I lipca 1901 r. pierwszorzędne biuro nauczycielskie Jaholkowskiej przeniesione zostaje z ul. Marszalkowskiej nr 143 na $\mathrm{nr} 118$. Poleca: Polki z wyższym i średnim wyksztalceniem, nauczycieli, korepetytorów, Francuzki, Niemki, Angielki, bony Polki, Freblówki, gospodynie, zarzqdzajace domem itp. Dzial cudzoziemek prowadzi Jadwiga Jaholkowska, byla nauczycielka II gimnazjum. Dzial nauczycielek Polek oraz freblówek wychowawczyń prowadzi Ludwika Jaholkowska, przeoczona zaklodu freblowskiego, istniejacego od 12 lat przy ul. Wspólnej 40 w Warszawie, „Tygodnik llustrowa-
ny" 1901, nr 23 .

${ }^{88}$ Zakład freblowski Marii Jadwigi Keller obchodził w 1901 r. dziesięciolecie istnienia. Jak podawał "Tygodnik Ilustrowany" w szkole tej w okresie jej działania wykształciło się 50 uzdolnionych freblówek, a w tej liczbie bezpłatnie wyuczyło się kilkanaście sierot, które tym sposobem zyskały środki utrzymania,
w. Kronika Powszechna, „Tygodnik Ilustrowany” 1901, nr 7, s. 138 . 
le zajęć teoretycznych, odbywało się bardzo wiele zajęć praktycznych. Uczono tu panienki uważnego czytania, dziejów narodowych, higieny, prac gospodarskich (gotowania, prania, prasowania, robienia przetworów), rachunków gospodarskich, katechizmu, śpiewu, rysunków, prac ręcznych (szycia, haftu, koronkarstwa, introligatorstwa) ${ }^{89}$. Właśnie ze szkoły hrabiny Zamoyskiej pochodzą opublikowane w książce Walerii Puffke liczne, wnikliwe i bardzo szczegółowe rady dla piastunek i bon do młodszych dzieci, służące uczennicom tego zakładu (wykorzystane również w niniejszym opracowaniu). Podobny zbiór porad w sprawie wychowania i opieki nad dziećmi dla matek, bon i piastunek, ułożony według 10 przykazań Bożych wydał Zakład Kórnicki w 1907 r. ${ }^{90}$ Jak pisała Waleria Puffke: $Z$ tego zakładu wyszło już wiele wykształceńcszych piastunek $i$ bon do mlodszych dzieci, odznaczajacych się pobożnościq, skromnościq i znajomościq swojego zawodu ${ }^{91}$.

Gdy powstały kursy freblowskie i szkoły bon, a co za tym idzie kształciły się w nich Polki, wymagania wobec bon i opiekunek dzieci nieco się zmodyfikowały. W końcu XIX i w początku XX w. aktualne oczywiście były wszelkie dotychczasowe zalecenia, lecz dodatkowo wymagano od bony, by znała gruntownie język polski, a także potrafiła wpoić w dziecko zamiłowanie do wszystkiego co polskie, do mowy polskiej historii, tradycji narodowych. Zalecano, by uczyła dzieci wierszyków narodowych, piosenek, imion królów, świętych, bohaterów, artystów, malarzy itp. ${ }^{92}$ Prócz tego bona powinna wykazać się gruntowną znajomością metody Froebla, a więc powinna umieć zająć dziecko różnymi pracami ręcznymi i rozwijać jego zdolności manualne ${ }^{93}$. Konieczna była także znajomość zasad wychowania fizycznego i umiejętność prowadzenia różnorodnych gier i zabaw dla dzieci, a jak twierdzono, bona, która miala szczęście przejść kurs nauki freblowskiej, nigdy nie będzie $w$ klopocie czym dziecko zajq̨ć $i$ zabawićs . Dlatego też te bony, które

${ }^{89}$ Bardzo dokładną charakterystykę sposobu funkcjonowania szkoły, a także dokładny program nauczania, plany zajęć dla kursów i oddziałów różnych stopni, odnaleźć można w: Zaklad kórnicki. Szkola Domowej pracy w Zakopanym, nakladem Biblioteki Kórnickiej 1913; Dr K. Krotoski, Zaklad hrabiny Zamoyskiej w Zakopanym, „Przegląd Powszechny” 1897, tom 53, ss.131-144, a także: Z. Nowak, Historia Zakladu Kórnickiego, cześć II - Zakopane-Kuźnice, wrzesień 1889 - lipiec 1914, „Pamiętnik Biblioteki Kórnickiej”, Kómik 2003.

${ }^{90}$ Patrz: Zaklad Kómicki o wychowaniu, Poznań 1907.

${ }^{91}$ Zabawy, gimnastyka, pogadanki..., s. XII.

${ }^{92}$ Ibidem, s. 511-512.

${ }^{93}$ Na lamach „Przegląu Pedagogicznego”, na potrzeby kształcenia wychowawczyń dzieci w wieku przedszkolnym zamieszczano szereg artykułów o charakterze poradnikowym z zakresu zabaw dzieci, sposobów prowadzenia zajeć, wykorzystywania w pracy $\mathrm{z}$ dzieckiem metody Froebla. Najistotniejsze były działy prowadzone przez Marię Weryho, Zabawy i zajęcia dzieci w wieku przedszkolnym oraz Ogródek Dziecięcy, który zawierał materiahy $i$ wskazówki do gier, śpiewów, pogadanek i zajęć z matymi dziećmi, „Niwa” 1895, nr 4, Warszawa, s. 73.

${ }^{94}$ Zabawy, gimnastyka, pogadanki..., s. 506; Repertuar gier i zabaw dziecinnych, rozwijających zarówno stronę fizyczna jak i intelektualną dziecka, byl bardzo bogaty. Zalecano szczególnie zabawę w odgadywanie zagadek, wykorzystywanie do zabaw obrazków poglądowych i powiastek. Korzystnym było, gdy rodzice prenumerowali jakieś pismo dziecinne, np. lwowski "Mały Światek”, warszawskie „Moje Pisemko" czy „Przyjaciela Dzieci”, w których bona znaleźć mogła obfity materiał do opowiadań i wierszyków. Gry ruchowe, w zależności od pory roku, można było prowadzić w pokoju, z wykorzystaniem różnorodnych zabawek, w zimie zalecano domowe gry biegające, wprawiające w ruch cały organizm dziecka. $Z$ zabaw na świeżym powietrzu zalecano szczególnie przechadzki, lączone z poglądową nauką przyrody, uprawę ogródka dziecinnego, za: ibidem, ss. 504-510. 
ukończyły kursy freblowskie były szczególnie przez rodziców poszukiwane i chętnie zatrudniane ${ }^{95}$.

Nie ominęła jednak freblanek i szkół froeblowskich krytyka. Jan Władysław Dawid pisał, iż zwykle freblanki to dziewczęta $\mathrm{z}$ wykształceniem elementarnym, których odbycie krótkiego kursu w szkole bon nie jest w stanie przygotować do podjęcia tak odpowiedzialnego zadania, jakim jest wychowanie małych dzieci. Nawet przeciwnie, oddawanie się przez dluższy czas tak mechanicznym zajęciom jak wycinanie, wykluwanie, wyplatanie [...] na umystowość ogólnq osób starszych wplywa może samo przez się raczej ujemnie niż dodatnio ${ }^{96}$. Zdaniem zaś Anieli Sobolewskiej, istniejące w Królestwie Polskim kursy freblowskie nie sq jednak w stanie sprostać swemu zadaniu. Skromne środki, którymi rozporzqdzaja, każa im się przede wszystkim liczyć z ideq zwiqzania końca $z$ końcem. Na kursy te przyjmujq więc wszystkie kandydatki bez wyjątku, wyklady zaś utrzymane sa na bardzo niskim poziomie [...] Radykalnie zaradzić złemu moglibyśmy jedynie, zakładając

\footnotetext{
${ }^{95}$ Np. Potrzebna bona Polka - pierwszeñstwo Królewiance, do dwojga dzieci, „Dziennik Kijowski” 1913, nr 114. Również bony, poszukując pracy wyraźnie podkreślały fakt ukończenia tego typu szkoły, np.: Mloda osoba, skończyla zakiad freblowski w Warszawie, poszukuje miejsca przy dzieciach, „Kraj” 1905, nr 22; Wyksztalcona Polka, freblanka, z dobra muzyka poszukuje miejsca na stale, „Kraj” 1903, nr 38; Froeblistka, $z$ ukończeniem kursów Jaholkowskiej w Warszawie, $w$ wyksztalceniem, posiadajqca jezyk niemiecki, poszukuje zajęcia, „Kraj” 1903, nr 35; Freblanka Polka, doskonaty niemiecki, praktyczny polski, przyjmie stala posadę do dzieci do Kamienia Podolskiego lub na wieś, „Dziennik Kijowski” 1913, nr 272. Jak wynika $\mathrm{z}$ ogłoszeń, freblanki zatrudniały się $\mathrm{w}$ domach polskich nie tylko na stałe, ale i na godziny; np.: Freblanka $z$ doskonalym polskim, niemieckim, ma wolne godziny z rana od 10 do $12 i$ wieczorem od 7 , „Dziennik Kijowski" 1913, nr 45; Freblanka $z$ doskonatym niemieckim $i$ polskim ma godziny wolne od 12 do 2 i od 5 do
} 7 wieczorem, „Dziennik Kujawski” 1913, nr 89.

${ }^{96}$ J. Dawid, Nasze freblanki, „Przegląd Pedagogiczny” 1896, nr 20, s. 362; Podobne zdanie na temat freblanek miała Waleria Puffke, uważając, iż rzadko zawodowi temu poświęca się osoba $z$ wyższym wykształceniem, najczęściej zaś podejmuja się go panny, które ukończyły szkołę średnia w najlepszym razie wyższą szkołę żeńską, bądź odebrały jedynie domowe wychowanie, pełne braków i niedostatków. Jeśli nawet freblówki uczą się w specjalnym zakładzie, to nauka trwa zbyt krótko, by przygotować je w sposób gruntowany do podjęcia odpowiedzialnego zadania wychowania małego dziecka. Dlatego też stworzyła ona podręcznik do gier, zabaw i pogadanek dla freblanek, zalecając, by one same stosowały się do zawartych w nim zaleceń i ciągle doskonaliły swój warsztat pracy przez czytywanie książek i poradników o podobnym charakterze, za; W. Puffke, op.cit., ss. VI-VII; książek takich na przełomie XIX i XX w. ukazało sie dość dużo, np.: Metoda Froebla. Maly introligator dla pracowitych dzieci, 1873; Metoda Froebla. Mlotek i gwóźdź dla pracowitych dzieci, Warszawa 1873; T. Nowosielski, Pokój dziecinny. Podręcznik dla matek $w$ duchu froeblowskim, wedlug niemieckiego dziela Tekli Naveau, z 20 tablicami wzorków litografowanych, zawierajacy poglqdowy sposób rozwijania umyslu i serca dzieci, od lat 3 do 6, przez praktyczne zajęcie odpowiednimi odpowiedniemu ich wiekowi robotami ręcznymi, przeplatanymi krótkimi powiastkami, bajeczkami, piosenkami i wierszykami, Lublin 1877; Ukladanie figur w liniach prostych. Zabawka dla dzieciaczków od lat 4 podlug metody freblowskiej, z objaśnieniami A. Dygasińskiego, Warszawa 1882; M. Weryho, Spiewy $i$ zabawy dziecięce w pokoju $i$ w ogrodzie. Warszawa 1889; M. Weryho, Spiewy i zabawy w domu, w ogrodzie, marsze i śpiewki z towarzyszeniem fortepianu oraz gry w pilkę i gry towarzyskie. Ksiqzeczka dla matek $i$ wychowawczyń, Warszawa 1890; J. Warnkówna i L. Jahołkowska, $W$ ogródku dziecięcym. Zbiór zabaw, marszów i piosenek z zastosowanq do nich melodiq, Warszawa 1895; M. Weryho, M. Art-Golczewska, Co z czego się robi i skq̨d pochodzi: zbiór praktycznych wskazówek dla wychowawców i nauczycieli poczqtkowych, Warszawa 1905; J. Chrzaszzewska, Lutnia dziecięca. Marsze, zabawy, piosnki, wyd. III, Warszawa 1907; M. Weryho, Jak zajać dzieci w wieku przedszkolnym: pogadanki, rozmowy, zabawy $i$ robótki, Warszawa 1907; M. Weryho, Zabawy i zajęcia dziecięce, Warszawa 1907; M. Weryho, Gry i zabawy towarzyskie w pokoju i na dworze, Warszawa 1910; J. Warnkówna, L. Jahołkowska, W ogródku dziecięcym. Zbiór zabaw, marszów i piosenek na l glos z towarzyszeniem fortepianu, Warszawa 1910; J. Chrząszczwska, J. Warnkówna, Na wieczornicy. Podręcznik dla ochroniarek, Warszawa 1913. 
dla wychowawczyń domowych specjalne szkoty, oparte na stalej pomocy materialnej, które miałyby możność segregowania kandydatek, tj. skierowywania na innq drogę osób malo odpowiednich dla sprawy wychowania $i$ byly $w$ stanie dać osobom uzdolnionym w kierunku pedagogicznym gruntowne przygotowanie ${ }^{97}$.

Mimo wszystkich tych zarzutów, faktem jednak było, iż z czasem zatrudnianie bon Polek stało się coraz bardziej popularne nie tylko w Królestwie Polskim, gdzie szkół kształcących freblanki było najwięcej, ale i we wszystkich zaborach ${ }^{98}$. Cudzoziemki jednak nadal znajdowały zatrudnienie w większości możnych domów ${ }^{99}$. Porównując kwalifikacje i przygotowanie Polek i cudzoziemek, okazywało się, że bony Polki, które posiadały, tak krytykowane przez Dawida, przynajmniej elementarne, a często nawet i średnie wykształcenie, znały dobrze język rodzimy, a przy tym niejednokrotnie przeszły kurs teoretyczny i praktyczny z zakresu wychowania dzieci, doskonale wywiązywały się z obowiązku opieki nad młodszymi dziećmi. Jakkolwiek niesprawiedliwościq byloby twierdzić, że wychowawczynie cudzoziemki zastugujq na potepienie, a wszystkie Polki sq wzorowe, doświadczenie jednak poucza, że tak się dzieje niemal dziewięć razy na dziesięć $i$ że owe doskonate bony zagraniczne, należq do takich wyjątków, iż potwierdzaja tylko regulę ${ }^{100}$.

By bona dobrze sprawowała powierzone jej obowiązki, konieczne było zapewnienie jej odpowiednich warunków bytu. Publicyści pedagogiczni ze wszystkich trzech zaborów zgadzali się co do zaleceń w kwestii warunków, które należało stworzyć bonie, by odpowiednio sprawować mogła swe obowiązki. Zalecano matkom wygospodarowanie w pokoju dziecinnym osobnego kącika, gdzie mogłaby spać i przechowywać swe rzeczy i dbać o higienę ${ }^{101}$.

\footnotetext{
${ }^{97}$ A. Sobolewska, op.cit., s. 78.

${ }^{98} \mathrm{~Np}$. Bonę freblowska I klasy, która ma pozwolenie rejencyjne, mówiqcq wyborowa polszczyznq, znającq takie jezyk francuski, muzykalna, poszukujemy dla 2 dzieci, "Głos Wielkopolanek" 1908, nr 26; Potrzebna freblanka w średnim wieku, do 4-letniego chlopczyka, „Głos Wielkopolanek” 1908, nr 4; bony także wykształciwszy się w szkółce froeblowkiej, gotowe były wyjechać w inne części kraju, np. Freblanka z Warszawy poszukuje miejsca do małych dzieci, „Dziennik Kijowski” 1913, nr 45; Poczqtkowa nauczycielka z Warszawy, z feoeblowskq metodq i gimnastykq poszukuje zajęcia, „Kraj” 1903, nr 38.

${ }^{99}$ Słuszna byla uwaga „Życia", donoszącego o otwarciu szkoły bon i piastunek w Warszawie: jeżeli zaklad ten funkcjonować będzie prawidlowo i umiejętnie, moze oddać rodzicom wielkie przyslugi, jakkolwiek nigdy nie zabraknie takich państwa, którzy będa, choćby tylko dla dobrego tonu, powierzać swe dziatki wywlokom cudzoziemskim., w: Z objawów życia, s. 639.

${ }^{100}$ W. Marrene-Morzkowska, Jeszcze o bonach cudzoziemkach, „Tygodnik Ilustrowany” 1897, nr 25, s.489; Rodzice zdawali się być zadowoleni z zatrudniania właśnie bon Polek, freblanek. W jednym z listów babki do wnuczki, mówiącym o wychowaniu dzieci, babka pisze: To dobrze, to bardzo dobrze, że wbrew modzie wzięlaś do dzieci twoich bonę Polkę. Cieszy mnie także, że bona twój kurs Froebla odbyla; oby nareszcie ten ważny obowiqzek przestano po amatorsku traktować, w: Listy mojej babki, s. 384; Teodor Toeplitz, poszukując bon do opieki nad swoimi dziećmi, spośród wielu kandydatek wybrał Polkę, Mloda, 18 lat, śpiewajaca, wyksztalcenia 5 lat i szkola freblowska, w: K. T. Toeplitz, op.cit., s. 258 (Królestwo Polskie); Również Helena Obiezierska wspominała bonę swych kuzynów, pannę Janinę Jaworską jako milq $i$ mqdrq freblanke, zwanq przez dzieci paniusia, w: H. Obiezierska, Jedno życie prywatne na tle żcia narodu polskiego $w$ wieku XX, Bydgoszcz 1995, s. 24 (zabór rosyjski).

${ }^{101}$ Karolina Nakwaska opisując urządzenie pokoju dziecinnego w wiejskim dworze bardzo dokładnie opisała zalecenia co do warunków, jakie matki powinny stworzyć bonom, np. Nie odmawiaj osobnego miejsca na rzeczy bony [...] inaczej wszędzie jej graty na przeszkodzie ci będa. Dla bony daj inne jak dla nich (dzieci) narzędzia czystości. Ręcznik dla niej osobny, dla dzieci inny. Bo tego nie możesz wymagać, aby się myla, jeżeli jej nie ulatwisz tej ważnej sprawy. Dwa ręczniki dla dzieci na tydzień; jeden dla ich slużqcej: to dosyć, w: K. Nakwaska, op.cit., s. 38.
} 
Istotne było także odpowiednie traktowanie bony w domu pracodawcy ${ }^{102}$. Jednak o wiele ważniejsze dla należytego sprawowania powierzonej jej roli było porozumienie jej $\mathrm{z}$ matką lub obojgiem rodziców dziecka. Zalecano, by matka $\mathrm{z}$ bona zaraz po zatrudnieniu tej ostatniej, wspólnie ustaliły zakres obowiązków wychowawczyni, a także pewien plan wychowania i zasady, którymi będą w wychowaniu dziecka się kierować. Dobrze byłoby, by matka i bona kontaktowały się niemal codziennie, decydowały o kierunku wychowania dzieci, o zwalczaniu ich wad i wybryków ${ }^{103}$. Czynić to powinny bez obecności dzieci, które nie słysząc zarzutów matki wobec bony, darzyć będą tę ostatnią szacunkiem i zaufaniem ${ }^{104}$. Powinny ustalić stały plan dnia dziecka, którego należało dokładnie przestrzegać $^{105}$. Matki, jak sugerowała Aniela Sobolewska, powinny nawet zachęcać wychowawczynie do pogłębiania swoich wiadomości z zakresu opieki nad dzieckiem, a więc do czytania książek $\mathrm{z}$ dziedziny wychowania i do uczęszczania na wykłady wieczorne (w mieście) ${ }^{106}$.

Jak wynika $\mathrm{z}$ analizowanych źródeł, bony były różnie traktowane w domach swych podopiecznych. Jak podawał A. Potocki: co do swego stanowiska $w$ rodzinie, bona jak wiemy, zajmuje miejsce pośrednie miedzy tzw. oficjalistami a stugami ${ }^{107}$. Zalecano matkom odpowiednie szanowanie wychowawczyni, traktowanie jako członka rodziny, otaczanie uprzejmością i serdecznościa, pozostawianie jej czasu wolnego na własne zajęcia, a także dbanie o jej wygode i zdrowie. Bony powinny też za swą pracę otrzymywać odpowiednie wynagrodzenie - im zastugi sa większe, tym więcej wynagradzane być powinny ${ }^{108}$. Często, obok obowiązku wychowania dziecka, wymagano od bon różnych dodatkowych prac, np. szycia, reperowania bielizny, sprzątania, a także pomocy w zarządzanie całym gospodarstwem domowym ${ }^{109}$. Jak pisała Aniela Sobolewska, większość absolwentek kursów freblowskich traktowana była w wielu domach w mieście,

${ }^{102}$ Miej do niej (bony) zaufanie $i$ względy. Ale jq do twego stolu ani towarzystwa nie przypuszczaj, jadajqc $z$ dziećmi nie będzie miala ublizenia, ani krzywdy, a nie zepsujesz jej zbytniq poufalościa, w: $\mathrm{K}$. Nakwaska, op.cit., s. 168.

${ }^{103}$ Bona jest tylko wyręczycielkq matki, więc bez jej wiedzy nic przedsięwziqć nie może. Przed objęciem obowiazku niezbędnym jest, by zwierzyla się przed rodzicami lub opiekunami dziecka, jakimi zasadami rzqdzić sie będzie przy wychowaniu, w: Rodzina. Bona, s. 230.

${ }^{104}$ Jak radzila matkom Karolina Nakwaska: Nigdy na bonę nie mów nic przed dziećmi. Jeżeliś z niej niezadowolona, to jq odpraw; ale nie utyskuj, nie żal się na niq. Dzieci zaraz poznaja twe nieukontentowanie, stanq się krnqbrne $i$ nieposiuszne, a ten nalóg raz wzięty $i$ pod drugie rzqdy przechodzi, w: K. Nakwaska, op.cit., s. 168.

${ }^{105}$ Taki dokładny plan dnia dziecinnego, z wyznaczeniem godzin na odpowiednie czynności, od momentu wstania z łóżka, przez ubieranie, posiłki, zabawy, spacery, po sen, na każdą porę roku zawarła w swej książce W. Puffke, patrz: Rozklad dnia dziecięcego dla dzieci od 2.5 do 5 roku, w: Zabawy, gimnastyka i pogadanki, ss. 513-516.

${ }^{106}$ A. Sobolewska, W sprawie wychowawczyń..., s. 7.

${ }^{107}$ A. Potocki, Stugi - wychowawczynie..., s. 101.

108 J. Olszyc, op.cit., s. 276.

${ }^{109}$ Rodzina. Bona, s. 230; zdarzało się, że rodzice od początku wymagali od bony wykonywania innych prac niż tylko opieki nad dziećmi np. Potrzebna jest bona Polka freblówka, umiejqca dobrze szyć, "Kraj" 1893, nr 38, Petersburg, s.25. Również bony, poszukując pracy zaznaczały, iż posiadają daną umiejętność: Bona ptynnie mówiqca obiema językami krajowymi $i$ znajqca krawieczyznę, poszukuje miejsca od I stycznia - mówiło jednych z ogłoszeń, „Dziennik Kujawski” 1894, nr 291; Bona poszukuje miejsca. Umie szyć, „Kraj” 1905, nr 37. 
a szczególnie na wsi, w bardzo niewłaściwy sposób - nie zwracano na nie szczególnej uwagi w kole domowników, przy posiłkach obsługiwano jako jedne z ostatnich uprzywilejowanych osób ${ }^{110}$, ograniczano ich obecność do pokoju dziecinnego, nie zapraszano przy pobycie gości, a interesowano się nimi jedynie wtedy, gdy wywoływały czyjeś niezadowolenie $^{111}$. Dodatkowo matki często czyniły opiekunkom opryskliwe uwagi w obecności dzieci, co znacznie obniżało ich autorytet $w$ dziecięcych oczach ${ }^{112}$, a także swoimi zachciankami i zmiennymi kaprysami co do sposobów wychowania dziecka rozregulowywały pewien stały rozkład dnia. Wszystkie tego typu niekulturalne i niekonsekwentne zachowania ze strony rodziców podopiecznych utrudniały lub nawet uniemożliwiały ich porozumienie i współpracę $\mathrm{z}$ boną w wychowaniu dzieci. Lecz bywało, iż bony zachowywały $\mathrm{z}$ rodzinami, w których pracowały serdeczne stosunki i jak wspominał Melchior Wańkowicz $\mathrm{Na}$ święta zjeżdzaly się z matkami $i$ ciotkami dawne bony ${ }^{113}$. Różne także były stosunki bon z powierzanymi im dziećmi. We wspomnieniach pamiętnikarskich można odnaleźć kilka opisów, świadczących zarówno o serdecznych, jak o chłodnych i zdystansowanych relacjach $\mathrm{z}$ podopiecznymi ${ }^{114}$.

Bony Polki pochodziły najczęściej $\mathrm{z}$ ubogich rodzin mieszczańskich, były także wśród nich zubożałe szlachcianki, a nawet chłopki ${ }^{115}$. Bardzo wiele było dziewcząt, obdarzonych wrodzonym zamiłowaniem do dzieci, które, choć nie miały w tym kierunku specjalnego wykształcenia, miały już doświadczenie w pracy z dziećmi, gdyż opiekowały

\footnotetext{
${ }^{110}$ Jak wspominała Maria z Lubieńskich Górska, bony zwykle jadały posiłki przy osobnym stole, razem z dziećmi, w: M. Z Łubieńskich Górska, Gdybym mniej kochala. Dziennik z lat 1889-1895, Warszawa 1996, s. 10.
}

${ }^{111}$ A. Sobolewska, W sprawie wychowawczyń..., s.76; „Tygodnik Ilustrowany” w 1903 r. zamieścił na swych lamach krótką nowelkę, która opowiadał o życiu młodej, 20 -letniej bony w jednym z domów arystokratycznych. Niby to miala do swojego rozporzqdzenia bibliotekę w czterech jezykach, niby to widywala ludzi inteligentnych, kulturalnych, oddychala ich atmosferq, zyla u tych ludzi, ale nie żyla z nimi. Pan, pani, rodzina, goście - nie liczyli się z niq. Proszono ja wprawdzie, by przychodzila do salonu podczas bali $i$ rautów, ale nikomu nie przyszlo na myśl wciagnać jej do rozmowy. W tym ruchliwym domu, z wesolymi dziećmi, czula się samotnq [...] Czy nie mógl ktoś zrozumieć, ze ona pragnęla czegoś więcej niż slów pani: Niech pani przypilnuje dzieci przy kapieli. Czy Jaś nie ma już bólu glowy? Czy dziewczynki byby grzeczne przy lekcji?, w: Aleksandra, Życie za szklem, „Tygodnik Ilustrowany” 1903, nr 7, ss. 115-116.

${ }^{112}$ Sytuację zwrócenia uwagi bonje przy dzjecku wspomina Ksawery Pruszyński. Pisze on jednak, iż fakt taki miał miejsce tylko jeden raz, gdy bona wpajała chłopcu antysemickie poglądy: Niech pani nie mówi glupstw! - przenwala wiedy bonie matka. Utkwilo mi to w glowie, bo nigdy, przenigdy, nie pamiętam jesz$c z e$, by którąś z moich wychowawczyń zgromiono w taki sposób i to w mojej obecności. Zdaje się, ze ta nieszczęsna bona nie popasala u nas dlugo, w: K. Pruszyński, Wspomnienia, reportaże artykuly, t. 1, Warszawa 2000, s. 20 (zabór rosyjski).

${ }^{113}$ M. Wańkowicz, Szczenięce lata, Kraków 1987, s. 38 (zabór rosyjski).

${ }^{114}$ Bony byty różne - wspominała Anna Skarbek Sokołowska - czasem lepsze, czasem gorsze. Nauczyly mnie czytać po francusku, bo wszystkie byly Francuski. Do jednej z tych bon panny Leontyny, przywiazalam się tak mocno, ze na drugi dzień po jej wyjeżdzie myślalam, że umrę z tęsknoty, w: A. Skarbek-Sokołowska, Czas udręki czas radości. Wspomnienia, Warszawa 1977, s. 20. Kolejna bona, panna Mengolde, nie wzbudzała w dziewczynce sympatii, [...] nie tęsknilam za niq. Byla ona w stosunku do dzieci opryskliwa $i$ niecierpliwa, w: ibidem; Inną znienawidzoną boną była opiekunka Stanisława Grabskiego, pani Aniela, która karała chłopców za przewinienia klęczeniem w pokoju na podłodze posypanej grochem, w: W. J. Grabski, op.cit., s. 36 .

115 Jak wspominal Wojciech Kossak: Walkowa, mloda babe przywiozla sobie do Paryża na bonę dla nas moja matka. Jako panienka ze dworu znala ja przed laty jako dziewczynę ze wsi [...] byla przepysznym okazem jasnowlosej rasy mazurskiej, w: W. Kossak, Wspomnienia, Warszawa 1971, s. 46. 
się młodszym rodzeństwem, lub też takie, które, uzdolnione pedagogicznie, pobierały specjalne wykształcenie w tym kierunku, uzupełnione potem na kursach freblowskich ${ }^{116}$. Takie wychowawczynie zwykle odpowiadały oczekiwaniom matek i spełniały wszystkie niemal zalecenia co do tego, jaką dobra bona być powinna ${ }^{117}$.

Podsumowując przedstawione wyżej wstępne wyniki badań dotyczące roli bon w wychowaniu domowym dzieci polskich w okresie 1850-1914 można stwierdzić, iż zatrudnianie tego typu wychowawczyń domowych charakterystyczne było dla całego analizowanego okresu i miało miejsce na terenie całego kraju rozdartego między zaborców. Mimo upływu ponad 60 lat, bony angażowano niezmiennie głównie do nauki języków obcych (stąd szczególne powodzenie cudzoziemek - Francuzek, Niemek, Szwajcarek czy Angielek) a także do całodobowej opieki nad dzieckiem i prowadzenia pierwszych nauk w zakresie elementarnym. Zatrudniano je głównie w rodzinach możnych - szlachecko-ziemiańskich, mieszczańskich czy arystokratycznych, ale i w średniozamożnych rodzinach ziemiańskich i mieszczańskich, inteligenckich, urzędniczych czy kupieckich.

Jednakże narastające w ostatnich dziesięcioleciach wieku XIX ze strony publicystów pedagogicznych zainteresowanie problematyką bon cudzoziemek spowodowało szeroko zakrojoną krytykę tej najemnej siły pedagogicznej. Krytyka ta obecna była na łamach pism pedagogicznych, a także prasy pedagogicznej, kobiecej i rodzinnej na terenie wszystkich zaborów już od końca XVIII w., lecz wobec panującej, zwłaszcza w pierwszej połowie wieku XIX mody na cudzoziemszczyznę (szczególne francuszczyznę) pozostała bez większego echa. W końcu XIX w. krytyka bon cudzoziemek szczególnie nasilona była na lamach pism kobiecych i rodzinnych wydawanych na terenie Królestwa Polskiego, głównie zaś Warszawy, a także na terenie Prus, gdzie krytykowano zatrudnianie Niemek, które, jak sądzono, wynaradawiały młode pokolenie Polaków. Argumenty mówiące o pozostawiającym wiele do życzenia prowadzeniu moralnym kandydatek na bony, ich niskim pochodzeniu społecznym, nierzadko elementarnym zaledwie wykształceniu i konsekwencjach wychowawczych powodowanych przez takie opiekunki, wywołały wśród części społeczeństwa niechęć do cudzoziemek i skłanianie się ku zatrudnianiu bon Polek. W celu odpowiedniego ich wykształcenia zaczęto we wszystkich trzech zaborach zakładać specjalne szkoły, zakłady i kursy, w których młode kobiety mogły doskonalić swe umiejętności pracy z dziećmi. Największa liczba szkółek froeblowskich dla bon powstała w Królestwie Polskim, w Warszawie. Jednak mimo propagowania na stronach poradników wychowawczych adresowanych do rodziców, a także na łamach pism kobiecych, pedagogicznych i rodzinnych zalet tak wykształconych bon rodaczek, część rodzin nadal sprowadzała do opieki nad dziećmi cudzoziemki, które to, obok bon Polek, zatrudniane były w rodzinach polskich aż do odzyskania przez Polskę niepodległości.

\footnotetext{
${ }^{116}$ A. Sobolewska, W sprawie wychowawczyń..., s. 77.

${ }^{117}$ Niestety, wśród polskich bon bywały też i takie, które tym wymogom nie odpowiadały. Byly to zwykle niezamożne dziewczęta, które nie miały ani specjalnej wiedzy, ani doświadczenia, a swą praç z dziećmi pragnęły podreperować rodzinny budżet. Już w 1877 r. Jan Olszyc pisał, że: stanowisko bony najwiaściwsze byloby dla córek podupadbch obywateli ziemskich, urzędników itp., kiedy zly stan majatkowy lub inne jakie okoliczności nie pozwolity im odebrać wyższego naukowego uzdolnienia $i$ zajać posady nauczycielki, w: J. Olszyc, op.cit., s. 276.
} 


\section{ANEKS NR 1}

Tabela: Liczebność pamiętników z zaboru rosyjskiego, pruskiego i austriackiego z lat 1850-1914, wykorzystanych w analizach, $\mathrm{z}$ podziałem na pochodzenie spoleczne ich autorów

\begin{tabular}{|l|c|c|c|c|}
\hline \multicolumn{1}{|c|}{ Zabór } & \multirow{2}{*}{ Zabór rosyjski } & Zabór pruski & Zabór austriacki & Razem \\
\hline Szlachecko-ziemiańskie & 117 & 26 & 42 & 185 \\
\hline Mieszczańskie & 72 & 14 & 37 & 123 \\
\hline Chłopskie & 12 & 34 & 18 & 64 \\
\hline Robotnicze & 9 & 9 & 3 & 21 \\
\hline Arystokratyczne & 0 & 7 & 0 & 7 \\
\hline Razem: & 210 & 90 & 100 & 400 \\
\hline
\end{tabular}

\section{ANEKS NR 2}

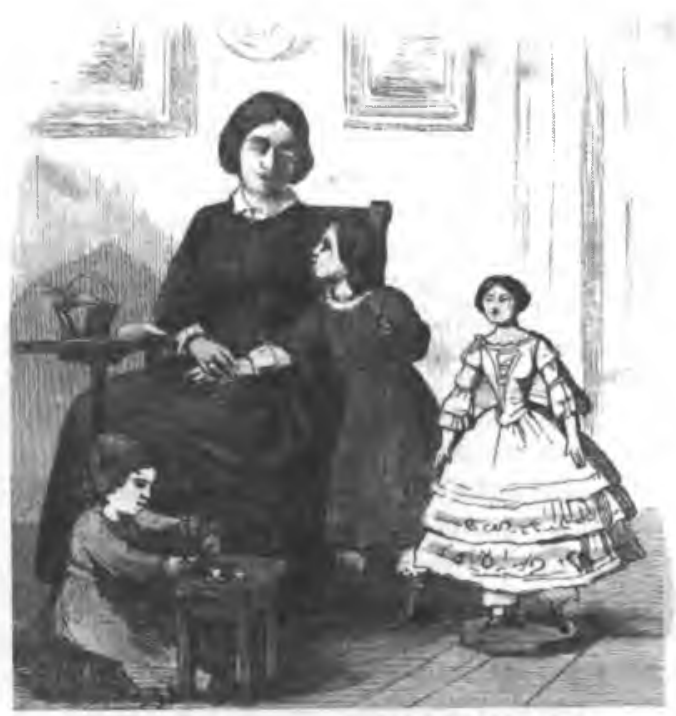

Bajki i powiastki Stanisława Jachowicza, Petersburg 1860, s. 21 


\section{ANEKS NR 3}

Konopnicka M., $W$ domu i w świecie. Ksiqzika dla dzieci od 10 do 12 lat, Kijów-Warszawa, br., s. 1
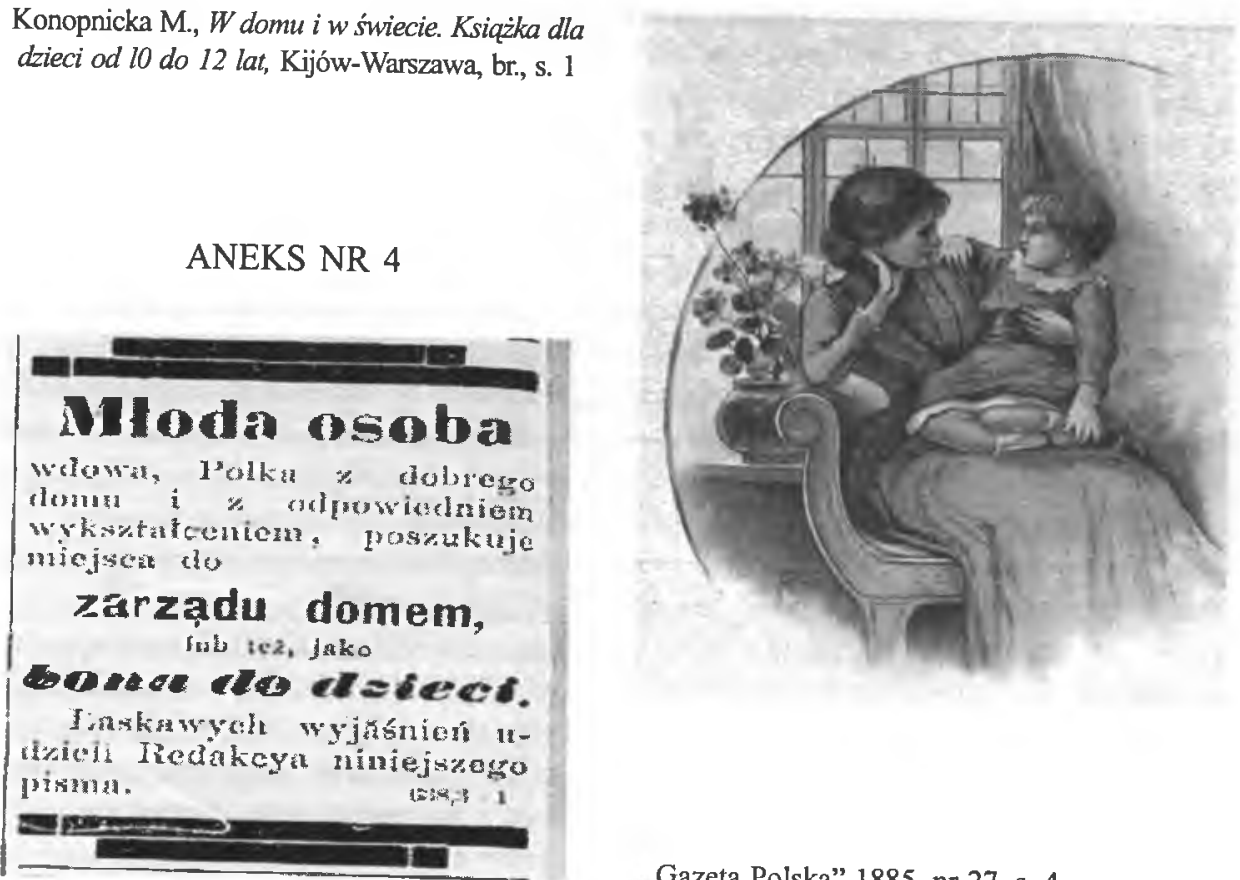

ANEKS NR 5

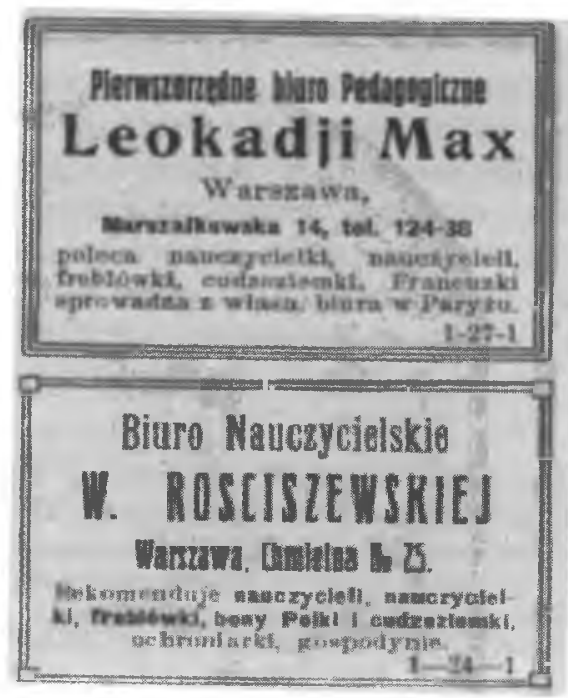

„Gazeta Polska” 1885, nr 27, s. 4 